(C) Yu.A. Ivanov, V.I. Byshev, Yu.A. Romanov, A.N. Sidorova, 2019, Journal of Oceanological Research, Vol. 47, No. 2, pp. 33-63

\title{
ON THE STRUCTURE OF THE NORTH ATLANTIC CURRENT IN MAY - JUNE 1990
}

\author{
Ivanov Yu.A., Byshev V.I., Romanov Yu.A., Sidorova A.N.
}

\author{
Shirshov Institute of Oceanology, Russian Academy of Sciences, \\ 36 Nahimovskiy prospekt, Moscow, 117997,Russia, e-mail: byshev.v@mail.ru \\ Submitted 15.01.2019, accepted 30.05.2019
}

"In the last quarter of the XX-th century, our country has implemented several major programs of experimental research of the World ocean. Among them, a special place was occupied by the huge in its scale and scientific significance the project SECTIONS aimed at studying the climatic interaction of the ocean and atmosphere. Currently, systematic research in this field has gained new momentum through regular Hydrophysical monitoring of the energy-active region in the North Atlantic in the annual expeditions by Shirshov Institute of Oceanology of RAS (Gladyshev et al., 2017). The results of some special Russian ocean expeditions of the past years, one of which is described for the first time in this article, can serve as a certain historical background for modern studies of the ocean climate evolution".

In 1990 Russian oceanographers carried out a comprehensive hydrophysical study of the Newfoundland energy-active zone in the Northern Atlantic ocean, as part of the national project "Sections" included in the international program WOCE. Three research vessels $(\mathrm{R} / \mathrm{V})$ of the Shirshov Institute of Oceanology (SIO): "Vityaz"(cruise 19), "Professor Stockman"( cruise 26) and "Academician Kurchatov" (cruise 50) together with additional 4 vessels of other institutions were engaged in the field study. Scientific management for general programme of the expedition, dubbed "ATLANTEX-90", was carried out by Professor Yu. A. Ivanov. The main objective of the program was to study the space-time short-period variability of water dynamics in the large - scale ocean circulation system of Gulfstream-North Atlantic Current. To this aim, in May-June 1990 R/V "Academician Kurchatov" performed several sections crossing the main hydrological fronts of the Newfoundland energy-active zone $\left(45-53^{\circ} \mathrm{N}\right.$., $\left.36-45^{\circ} \mathrm{W}\right)$. Observations were conducted using the cable probe with sensors of temperature, conductivity and pressure (CTD) and expendable bathythermograph (XBT). All this equipment was special made and passed metrological certification in the design Bureau of Oceanological Engineering (BOE) of SIO. The equipment metrology fitted in whole with international standards at that time.

The sea surface temperature (SST) was recorded along the RV route as well. The current velocity was measured during about one month at 14 moorings deployed on a section along meridian $36^{\circ} \mathrm{W}$, from 47 to $53^{\circ} \mathrm{N}$. The measurements were conducted using electronically operated current meters of POTOK type of the BOE of SIO production. The meters were installed on the each mooring at the horizons of 100, 200, 1000, 2000, $3500 \mathrm{~m}$. In addition to the data of own measurements, facsimile maps of SST from the nearest hydrometeorological observatories were received by radio communication channel during the whole period of observations.

Analysis of the obtained data showed that during the field study period the North Atlantic Current (NAC) divided into two branches (Central and Southern) roughly in the neighborhood of $47.5-48^{\circ} \mathrm{N}$, where isobath $4500 \mathrm{~m}$ turned to the East at right angle to isobath $4000 \mathrm{~m}$. After point of the bifurcation, the Central branch initially maintained a Northerly direction, then turned North-West along the isobath of $4000 \mathrm{~m}$, and farther, turning East, crossed the meridian of $36^{\circ} \mathrm{W}$ between $51^{\circ}$ and $52^{\circ} \mathrm{N}$. Prior that stage, the Central branch sometimes approached the meridian $36^{\circ} \mathrm{W}$ at about $50^{\circ} \mathrm{N}$, then deviated to the North-Northwest and finally turned North-East about $51,5^{\circ} \mathrm{N}$. The Southern branch of NAC after a split of the main NAC flow followed approximately to isobath $4500 \mathrm{~m}$, and crossed the meridian of $36^{\circ} \mathrm{W}$ at 
about $48^{\circ}$ North latitude. East of $36^{\circ} \mathrm{W}$ it could be at times of East-North-East direction, but usually this branch unfolded to the South-South-West, forming the high ridge of the ocean surface dynamic height on the Eastern flank of the NAC.

Three return flows were observed in the section of $36^{\circ} \mathrm{W}$. One of the flows is marked between the Central and Southern branches of the NAC, while the other two were recorded on the Northern and Southern edges of the section. This structure of the velocity field in fact remained unchanged through all June 1990. The basic zonal flow was observed in the entire water column within the depths from $100 \mathrm{~m}$ to $3500 \mathrm{~m}$. The highest current speeds were typical for the upper part of this layer. At depths of 1000-2000 m the velocities were noticeably weakened, increasing again in some places near the bottom.

The distribution of meridional components of flow speed according to the measurements on the buoys allowed us to detect the presence of large-scale divergence, which was located along the section on $36^{\circ} \mathrm{W}$. Direction of the meridional component of the current to the North and South of $49^{\circ} \mathrm{N}$ turned out to be the opposite, forming that divergence in the field of the velocity. Under the analysis of the observations it was taken into account that an important role in the formation of the structure of ocean circulation in the area of research could play a seamount $(>2600 \mathrm{~m})$, registered by the sounders of R/V "Academician Kurchatov" near $49^{\circ} \mathrm{N}, 36^{\circ} \mathrm{W}$.

The results of measurements and calculations showed that the average over the entire observation period water transport of the Central branch of NAC through the $36^{\circ} \mathrm{W}$ section accounted for $62.4 \mathrm{~Sv}$. This value is comparable to the transfer of NAC, assessed four years later by Lazer (1994) $50 \pm 23 \mathrm{~Sv}$ for approximately the same area where we conducted our work in 1990. Approximately the same average transfer (46,5 Sv) was found in two return flows (presumably North and South recirculations of the NAC Southern branch). In whole, the average water transport in the Eastern direction through the section on $36^{\circ} \mathrm{W}$ was as high as $111 \mathrm{~Sv}$., and it was $60.9 \mathrm{~Sv}$ after subtracting reverse fluxes.

Keywords: North Atlantic Current (NAC), Azores Current, Mid-Atlantic Ridge (MAR), Labrador Current, Gulf Stream, WOCE Program, Russian national Program "Sections", the 50th cruise of the R/V "Akademik Kurchatov"

\section{Introduction}

Fig. 1 shows the well-known North Atlantic Circulation scheme by Dietrich et al. (1975). It is based mainly on the data of the International Geophysical Year (1957-1958) and summarizes all previous knowledge on this subject. Near the SouthEast Newfoundland Rise about 40\% (29 Sv) of the combined Gulf Stream and slope waters turn SouthEast as the Gulf Stream Recirculation (known also as the Azores Current (AC) (Krauss et al., 1990)) and $60 \%$ of this transport (49 Sv) turn to the North along the slope of the Grand Banks to form the North Atlantic Current (NAC) (Mann, 1967; Clarke et al., 1980). The two-separate-gyre hypothesis of Worthigton (1976) is not generally supported now (e.g., McCartney and Talley, 1982; Krauss, 1986). The bifurcation of the Gulf Stream at this place is usually explained by the influence of the bottom topography, i.e., by the isobath divergence (Warren, 1969; Chuang Shi and Shen Yu Chao, 1994). Baryshevskaya (1985) noted an opposite tendency in the seasonal and interannual variations of the NAC and AC with the largest (smallest) volume transport in the NAC (AC) in April, May, and September and the smallest (largest) transport in the NAC (AC) in February and July. 


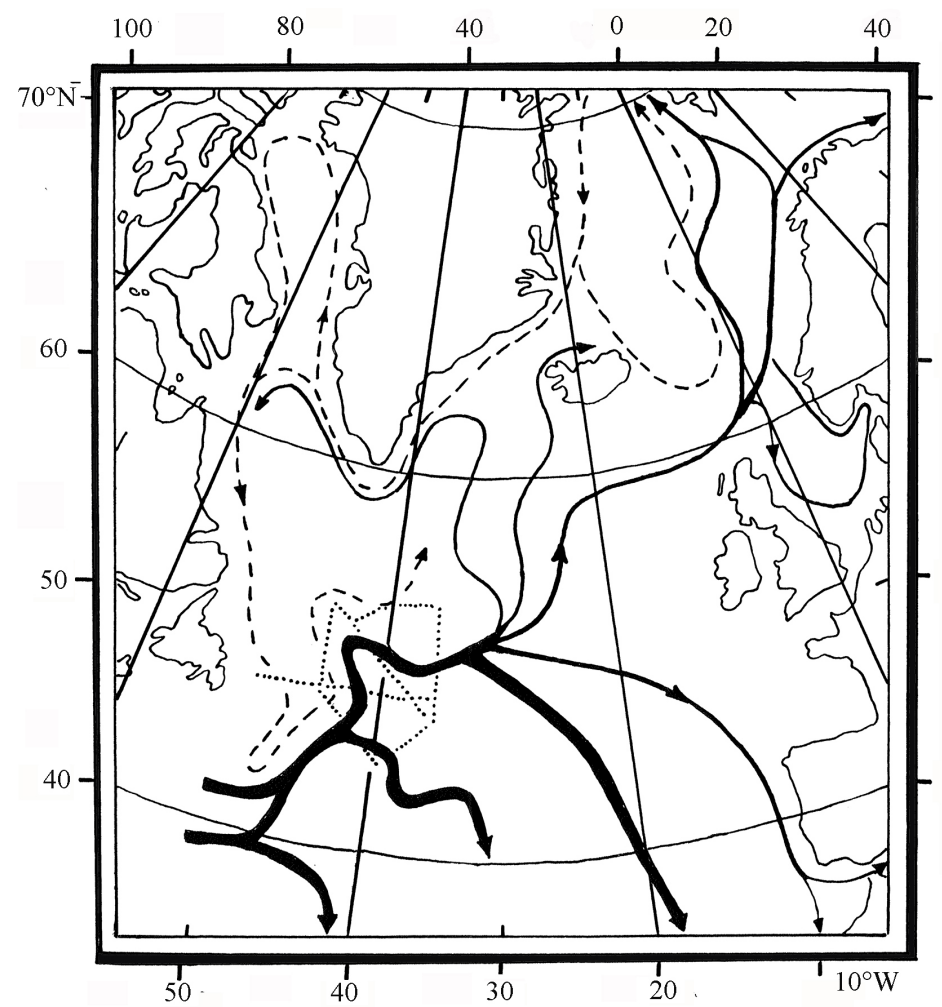

Fig. 1. Scheme of the currents in the North Atlantic (adopted from Dietrich et al., 1975). Dots indicate hydrographic sections made by the R/V "Akademik Kurchatov" in May-June 1990.

Mann $(1967,1972)$ identified the area at $42^{\circ} \mathrm{N}, 42^{\circ} \mathrm{W}$ as the centre of a permanent anticyclonic gyre. According to Dietrich et al., (1975) the Northern rim of this gyre is identical to the Southern Branch of the NAC (10 Sv), which separates from the Central Branch of the NAC near $45^{\circ} \mathrm{N}$ heading Southeast (see Fig. 1). However in 1984, Krauss (1986) did not find any permanent current branch here and only frontal jets were occasionally observed at different positions. Krauss et al. (1987) observed the NAC splitting into two branches at slightly higher latitude near $47^{\circ} \mathrm{N}, 41^{\circ} \mathrm{W}$ (Fig. 2). Part of the NAC, as it was also detected by Dietrich, turned to the North and Northwest toward the Northwest Corner of Worthington, while the remaining part continued to the Northeast. Near $48^{\circ} \mathrm{N}, 35^{\circ} \mathrm{W}$ the latter part of the NAC turned to the South and Southwest forming an elongated region of high pressure at the Eastern flank of the NAC and then turned again to the Northeast at $43-44^{\circ} \mathrm{N}$ forming a valley along the high pressure region. The region resembling a ridge and a valley were observed here earlier and are presented in the chart of the dynamic topography prepared by Stommel et al. (1978). Satellite-tracked drifting buoy observations of Krauss et al. (1987) indicate that the branching is yet a transient feature and that from both branches a considerable part of the transport was expelled into the return flows.

Arhan (1990) prepared a dynamic chart of the Newfoundland region combining observations in 1958 and 1964. Using also the TOPOGULF observations he confirmed that the Central Branch of the NAC goes along the continental slope isobaths ( $4000 \mathrm{~m})$ to the Northwestern Corner, turns there to the East, crosses the $35^{\circ} \mathrm{W}$ meridian at about 

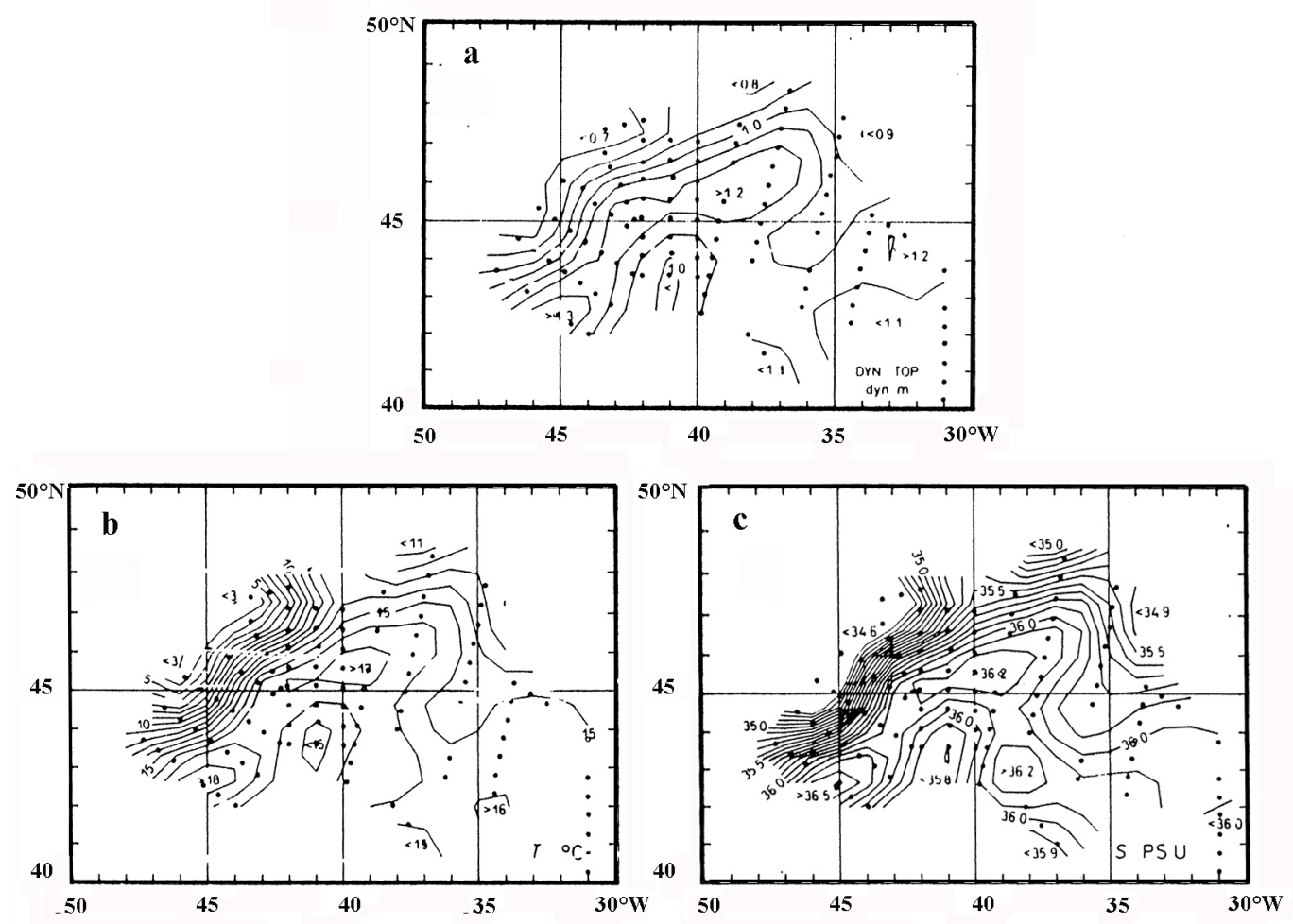

Fig. 2. Data of hydrographic observations in August 1983 (Krauss et al., 1987) and charts of the objective analysis: a - dynamic topography $100 / 150 \mathrm{db}, \mathrm{b}$ - temperature at $100 \mathrm{db}$, $\mathrm{c}-$ salinity at $100 \mathrm{db}$.

$51^{\circ} \mathrm{N}$ and heads then to the Charlie Gibbs Fracture Zone. The NAC Southern branch crosses the $35^{\circ} \mathrm{W}$ meridian at $47-48^{\circ} \mathrm{N}$ heading then to the Maxwell Fracture Zone. Part of this branch, as it was found by Krauss et al. (1987) (Fig. 2), turns to the Southwest going round the dynamic valley mentioned above. According to Arhan et al. (1989) this valley fits quite well the current observations at three TOPOGULF moorings deployed in the area $47-48^{\circ} \mathrm{N}, 34-35.5^{\circ} \mathrm{W}$. The upper mean velocity vectors at these moorings follow the dynamic contours on both sides of the valley thus revealing the spatial inhomogeneity of the flow and confirming the quasi-permanent nature of this feature.

Leach (1986) computed the current vectors from ship drift observations and showed that a marked Eastward water stream crossed the $35^{\circ} \mathrm{W}$ meridian in July-August 1981 between 51 and $52^{\circ} \mathrm{N}$. He showed also that in 1983 the Polar Front crossed the $35^{\circ} \mathrm{W}$ meridian at a higher latitude $\left(52.5^{\circ} \mathrm{N}\right)$ than in $1986\left(51.5^{\circ} \mathrm{N}\right)($ Leach, 1990). Bubnov (1994) analyzed the "Atlantex-90" current meter data and found that two Eastward streams associated with the NAC crossed the $36^{\circ} \mathrm{W}$ meridian near $50.5-52.5^{\circ} \mathrm{N}(61 \mathrm{~Sv})$ and near $48-49^{\circ} \mathrm{N}(47 \mathrm{~Sv})$. He also made a conclusion about the important role of the barotrophic flows in this region. Lazier (1994) reported the average transport of the NAC in the Northwestern Corner revealed from the current meter data (4 moorings, 8.5 month period of measurements). It comprised $50 \pm 23 \mathrm{~Sv}$ in the Northeastern direction. No significant variations in the direction of the flows throughout the whole water column were detected. Lazier (1994) concluded that high variability in the transport value which changed 
from $20 \mathrm{~Sv}$ to the Southwest to $120 \mathrm{~Sv}$ to the Northeast can be caused by the horizontal displacements of the current as well as by large anticyclonic eddies that were observed in the drifter trajectories. Baranov (1988) and Baryshevskaya (1990) while analyzing the Russian hydrographic observations conducted in the Newfoundland energetically active zone for several years also noted the existence of the two NAC branches in the region. The Southern Branch is not as stable as the Central one. It may change the place of its formation, its pattern, the volume of the transport, and sometimes it is not detectable. A similar conclusion was made by Sy (1988). According to Baryshevskaya (1990), in the vicinity of the $30^{\circ} \mathrm{W}$ meridian the Southern Branch may merge with the Central Branch of the NAC.

A fan of stream branches flowing out of the NAC near the Mid-Atlantic Ridge (MAR) might be seen in the scheme by Dietrich et al. (1975) (Fig. 1). The studies of Gana and Provost (1993) and Sy et al. (1992) confirmed the existence of several of these branches. New data on the circulation in this area were obtained within the abovementioned French-German "TOPOGULF" experiment in 1983-1984 (Sy, 1988; Arhan, 1990; Arhan et al., 1989).

Another Northward stream (shown with a dotted line in Fig. 1), which is called the Northern Branch of the NAC (Baranov, 1988), exists West of the Central Branch of the NAC. It is formed by the confluence of the slope water current and a part of the Labrador Current turning Northward near $43^{\circ} \mathrm{N}$.

The Labrador Current is associated with a secondary arctic front that separates very cold and low saline Labrador Current Water (or Canadian Coastal Arctic Water) from slightly warmer and more saline Labrador Sea Water. The Gulf Stream and the NAC are associated with a zone of large horizontal temperature and salinity gradients, which is the Polar Front (known also as the Subarctic Front and Subpolar Front). The Southeastern region of the Grand Banks where Labrador Current Water encounters much warmer North Atlantic Central Water is a region with the highest gradients and strong current fluctuations (Baranov and Ginkul, 1984; Heywood et al., 1994). East of Newfoundland the Polar Front separates relatively cold Labrador Sea Water from the warmer and more saline North Atlantic Central Water. The maximum temperature gradients are found at the depth of the stream core at about $200 \mathrm{~m}$, but strong gradients are usually observed also at the ocean surface along the left edge of the current (Krauss, 1986). The SST gradients on the Polar Front gradually decrease in the Northeastern direction and become smoother East of the MAR. In the Northwest Atlantic, the 35 PSU salinity marks quite well the boundary between the Labrador Sea Water and intermediate waters; thus it indicates the position of the Polar Front and the NAC at the sea surface (Baryshevskaya, 1990). Fahrbach and Wagner (1987) showed that in November 1983 and 1984 the $10^{\circ} \mathrm{C}$ SST isotherm was also a good indicator of this boundary. The upper layer heating in summer can mask the subsurface ocean circulation. In the Northwest Atlantic this occurs when the difference in temperatures at the sea surface and at $20 \mathrm{~m}$ becomes $5^{\circ} \mathrm{C}$ and greater. However when this difference is about $1{ }^{\circ} \mathrm{C}$ or less, the SST distribution reflects the pattern of the ocean circulation sufficiently well (Hardtke and Meincke, 1984). 
In this paper we present observation data on the NAC structure East of Newfoundland collected in May-June 1990 in cruise 50 of the Russian R/V "Akademik Kurchatov".

Section 2 of this paper contains a description of the observations. In Section 3 we analyze the observations at hydrographic sections during the cruise of the R/V "Akademik Kurchatov". We also identify surface isotherms, which can show the position of different NAC branches. In Section 4 we analyze spatial and temporal variations of different NAC branches by tracing the isotherm patterns on facsimile SST charts. The analysis of results of the current measurements at 14 moorings deployed along the $36^{\circ} \mathrm{W}$ meridian between 47 and $53^{\circ} \mathrm{N}$ are presented in Section 5. Summary and conclusions are given in Section 6.

\section{Observations}

Cruise 50 of the R/V "Akademik Kurchatov" was part of the "Atlantex-90" experiment carried out within the WOCE Program and the Russian national Program "Razrezy" ("Sections") (Gulev et al., 1992). In this cruise the ship occupied several hydrographic sections crossing the main ocean fronts and currents in the Newfoundland energetically active zone (Fig. 1). During the period of May 22-June 30, 1990, a total of 108 CTD stations were made with the measurements down to $2000 \mathrm{~m}$ separated by 20-30 miles (Fig. 3). Some sections were occupied using XBT casts with the same intervals to a depth of $500 \mathrm{~m}$. Sea surface temperature was recorded along all hydrographic sections using a pump for seawater from a depth of $3.5 \mathrm{~m}$. In addition, manual observations of
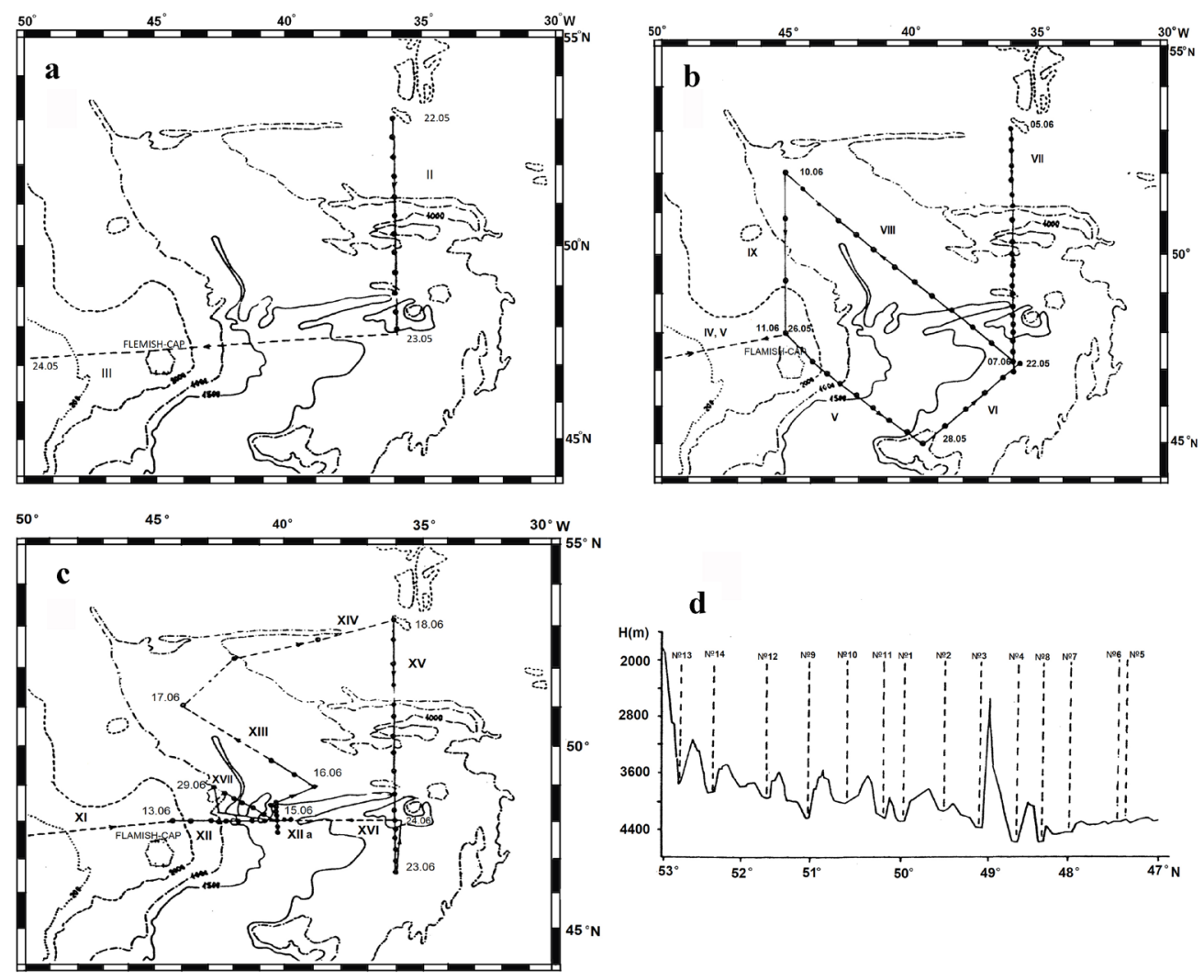

Fig. 3. Hydrographic observations during cruise 50 of the R/V "Akademik Kurchatov" in MayJune 1990: a - May, 22-24; b - May, 25-June, 11; c-June, 12-30; d-Mooring positions and the sea bottom profile along the $36^{\circ} \mathrm{W}$ meridian. 
SST (using surface bucket thermometer) within standard meteorological observations were made. Extensive observations were carried out at the section along $36^{\circ} \mathrm{W}$ (47$53^{\circ} \mathrm{N}$ ). They included the deployment of 14 autonomous moorings (Fig. 3d) with current and temperature measurements at 100, 400, 1000, 20006 and $3500 \mathrm{~m}$ (in the period of May 31-June 22, 1990); three CTD sections were made along this line. During inspections of moorings to check whether they are not displaced, the ship covered another three partial lines along this section with SST observations. Throughout the working period we received by radio the facsimile SST charts of the North Atlantic from five meteorological centers, which appeared to be very useful for our analysis. After the cruise, a number of papers were prepared on the basis of the data collected during the "Atlantex-90" experiment (Bubnov, 1994; Byshev, 1992; Byshev et al., 1993; Ivanov and Morozov, 1991; Koprova and Romanov, 1993; etc.).

In Fig. 3a, b, c the solid circles and dashed lines indicate the locations of CTD stations and XBT sections, respectively. Arabic numerals denote day and month, Roman numerals denote the number of the hydrographic section. Isobaths (dotted-dashed lines) are given according to the International Geological-Geophysical Atlas of the Atlantic Ocean (1989-1990).

\section{Hydrographic sections}

Sections II, VII, and $\boldsymbol{X V}$. Two main frontal zones are clearly seen near $51^{\circ} \mathrm{N}$ and between $48^{\circ}$ and $49^{\circ} \mathrm{N}$ over all three CTD sections made along the $36^{\circ} \mathrm{W}$ meridian (Fig. 4). It agrees with the front locations observed in this region by Arhan (1990) and Baryshevskaya (1990). Both frontal zones are characterized by the maximum temperature and salinity gradients at a depth of about $200 \mathrm{~m}$ and high gradients of these values at the sea surface. The Southern Front is deeper and slightly stronger than the Northern Front, but not at the sea surface; where temperature decreases a little smaller at the Southern Front $\left(2-3^{\circ} \mathrm{C}\right)$ than at the Northern Front $\left(4-5^{\circ} \mathrm{C}\right)$. The similar proportion was observed between the SST drops at the Southern and Northern fronts over the sections along the $35^{\circ} \mathrm{W}$ meridian described by Leach (1990).

The hatching denotes the current velocity directed out of the picture. The $2000 \mathrm{~m}$ depth was used as a reference level for the dynamic geostrophic computations. The SST at sections VII and XV was averaged over several passes of the ship along the section during the deployment of moorings and their inspection.

The Northern Front is well marked in the surface layers by the 35 PSU isohaline, usually considered as a boundary between the Labrador Sea Water and the Intermediate Water (Baryshevskaya, 1990). This isohaline deepens from North to South showing the expansion of the Labrador Sea Water in this direction under the Intermediate Water. The Southern Front is well marked by the 35.5 PSU isohaline, which separates the Intermediate Water from the North Atlantic Central Water (Baryshevskaya, 1990). Fig. 5 shows some examples of $T, S$-diagrams characteristic of the main water masses which are analyzed in this paper.

The $10^{\circ} \mathrm{C}$ isotherm marks well the location of the Northern Front at the sea surface over all three sections made along the $36^{\circ} \mathrm{W}$ meridian. The Southern Front is well indicated by the $13^{\circ} \mathrm{C}$ isotherm over section II (May, 22-23). The $14^{\circ} \mathrm{C}$ isotherm seems 
Ivanov Yu.A. et al.

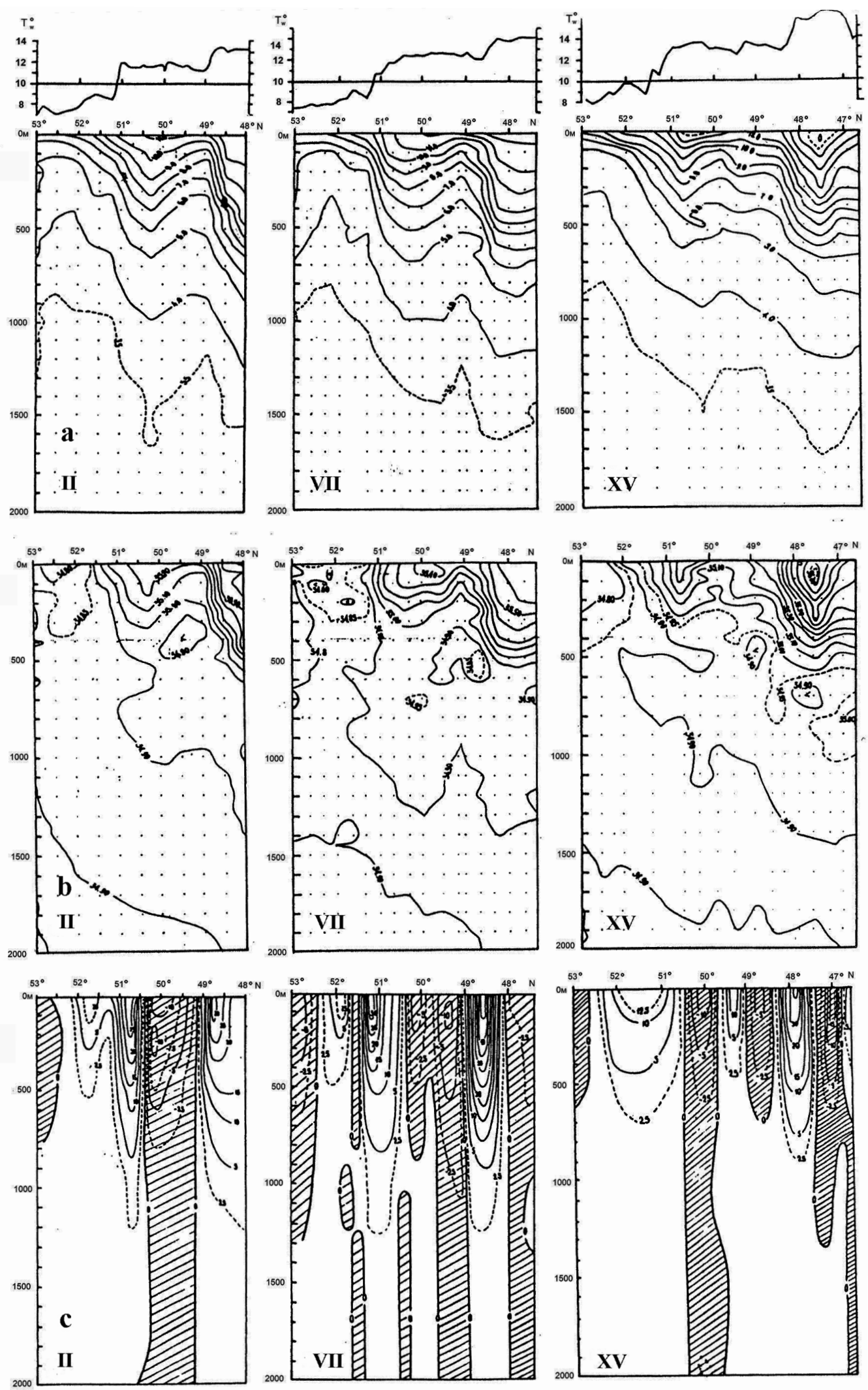

Fig. 4. Results of hydrographic observations at three CTD sections along the $36^{\circ} \mathrm{W}$ meridian: II (May, 22-23), VII (May, 29-June, 7), XV (June, 18-24), $t_{w}$ is the sea surface temperature; $\mathrm{a}$ - temperature, $\mathrm{b}$ - salinity, $\mathrm{c}-$ dynamic velocity $(\mathrm{cm} / \mathrm{s})$. 


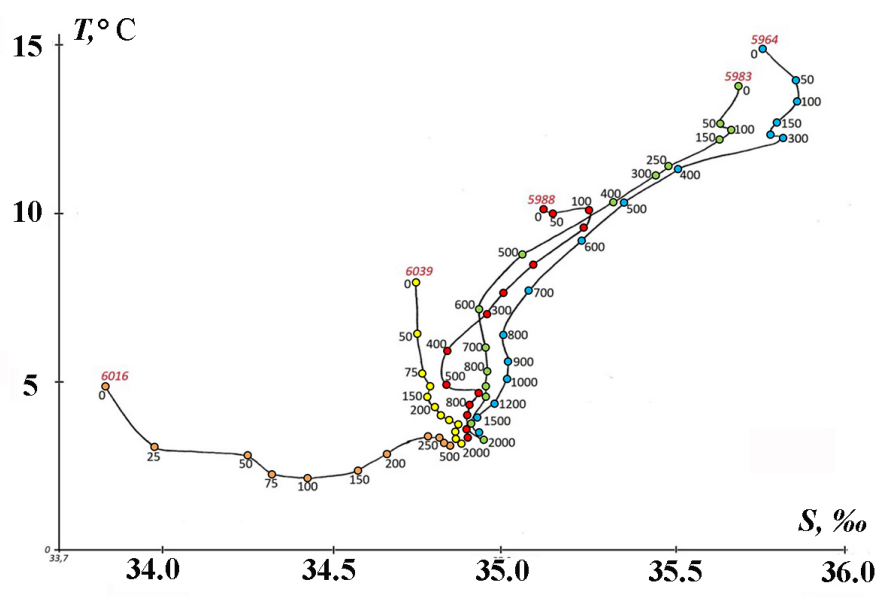

Fig. 5. $T, S-$ diagrams for the selected stations: 5964 ( $\left.45^{\circ} 54^{\prime} \mathrm{N}, 38^{\circ} 06^{\prime} \mathrm{W}\right), 5983\left(48^{\circ}\right.$ ' $21^{\prime} \mathrm{N}$, $\left.35^{\circ} 59^{\prime} \mathrm{W}\right), 5988\left(51^{\circ} 00^{\prime} \mathrm{N}, 36^{\circ} 01^{\prime} \mathrm{W}\right), 6016\left(48^{\circ} 00^{\prime} \mathrm{N}, 44^{\circ} 16^{\prime} \mathrm{W}\right), 6039\left(52^{\circ} 30^{\prime} \mathrm{N}, 36^{\circ} 00^{\prime} \mathrm{W}\right)$.

to be more appropriate for such an indication over the other two sections. The temperature differences at 0 and $20 \mathrm{~m}\left(\Delta T=0.20^{\circ} \mathrm{C}\right)$ were less than $1{ }^{\circ} \mathrm{C}$ over all three sections, which means that the summer heating of the upper layers was still not noticeable here.

The Northern Front location over all three sections along the $36^{\circ} \mathrm{W}$ meridian coincides with the Eastward geostrophic flow (Fig. 4), which can be interpreted as the Central Branch of the NAC. In the core of this flow the dynamic velocities varied from $12.5 \mathrm{~cm} / \mathrm{s}$ in the period June 18-24 (XV section) to more than $30 \mathrm{~cm} / \mathrm{s}$ in the period May 29-June 7 (VII section). Similarly, the Eastward flow at the Southern Front over these sections may be interpreted as the Southern Branch of the NAC as it is described by Arhan (1990) and Krauss et al. (1987). Dynamic velocities varied here from 30 to $50 \mathrm{~cm} / \mathrm{s}$ (Fig. 4c).

Section II (May, 22-23) displays the simplest dynamic velocity distribution with two Eastward streams: the Central and Southern branches (CBNAC and SBNAC) and with two weaker return flows $(5-10 \mathrm{~cm} / \mathrm{s})$. There is a secondary core near $51.5^{\circ} \mathrm{N}$ $(7.5 \mathrm{~cm} / \mathrm{s})$ at this section besides the main core of the CBNAC near $50.5^{\circ} \mathrm{N}(25 \mathrm{~cm} / \mathrm{s})$. Sections VII and XV were extended to the South and were carried out for longer periods (7-10 days) since this work was combined with the deployment of moorings, their inspection, and their recovery during rough weather. These sections show more complicated flow patterns, with a return flow $(15 \mathrm{~cm} / \mathrm{s})$ appearing South of the SBNAC near $47^{\circ} \mathrm{N}$. It will be shown later that this return flow is not related to the local eddy, but rather to the SBNAC recirculation similar to that shown in Fig. 2. Section VII shows the two core structures of the CBNAC more distinctly than section II. Section XV shows one core structure of the very weak CBNAC, but it reveals the two core structures of the SBNAC. All these flow features will be discussed later in detail.

Sections IV, $\boldsymbol{V}$ and $\boldsymbol{V I}$. The XBT section IV and two Southern CTD sections V and VI (Fig. 6) cross four frontal zones, which are clearly seen on the SST profiles. Near $46.5^{\circ} \mathrm{W}$ the SST increases from 1 to $4^{\circ} \mathrm{C}$; this gradient zone separates the Labrador Current Water in the area of the Grand Banks, which are characterized by a very cold $\left(<-1^{\circ}\right)$ subsurface layer from the shelf waters located over the Flemish Pass and Flemish 
Ivanov Yu.A. et al.
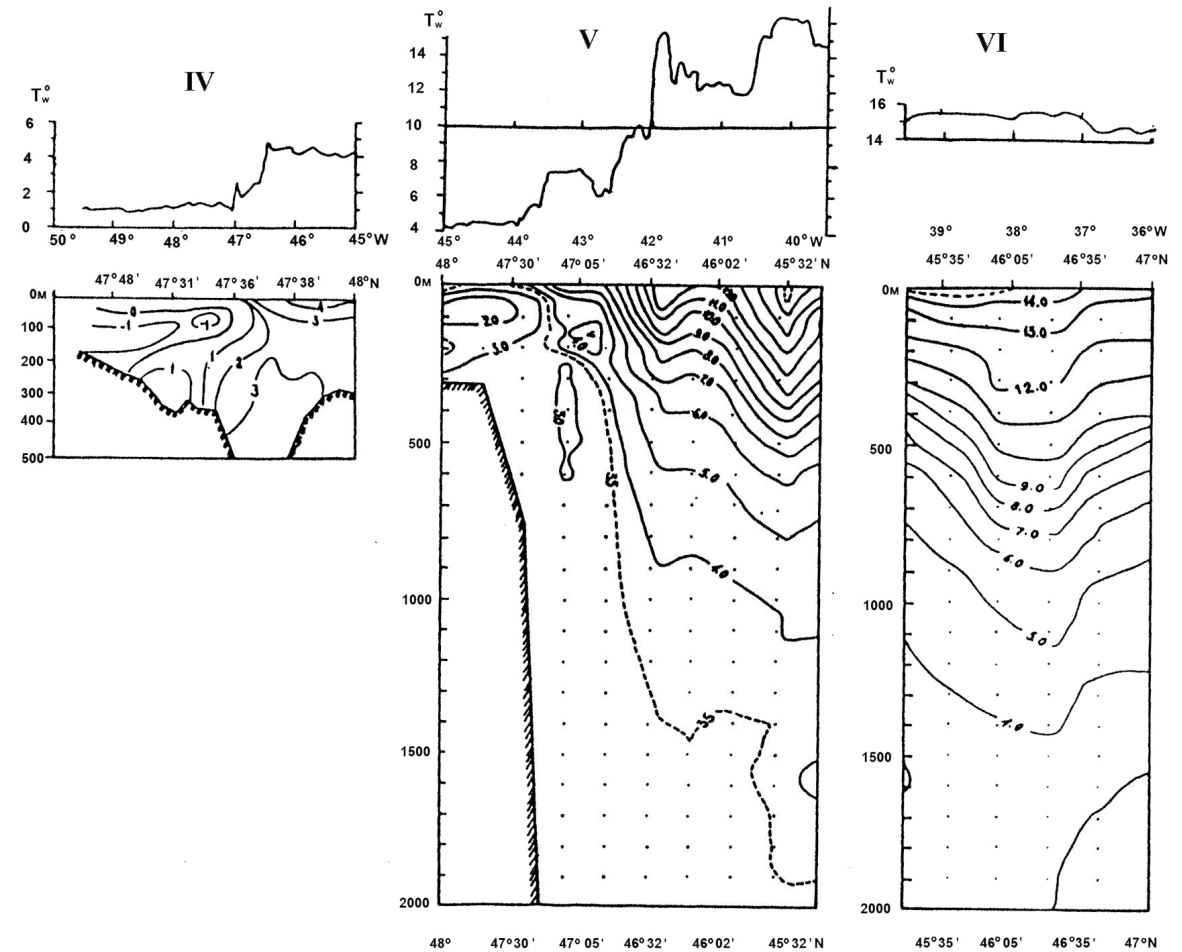

$48^{\circ} \quad 47^{\circ} 30^{\prime} \quad 47^{\circ} 05^{\prime} \quad 46^{\circ} 32^{\prime} \quad 46^{\circ} 02^{\prime} \quad 45^{\circ} 32^{\prime} \mathrm{N}$
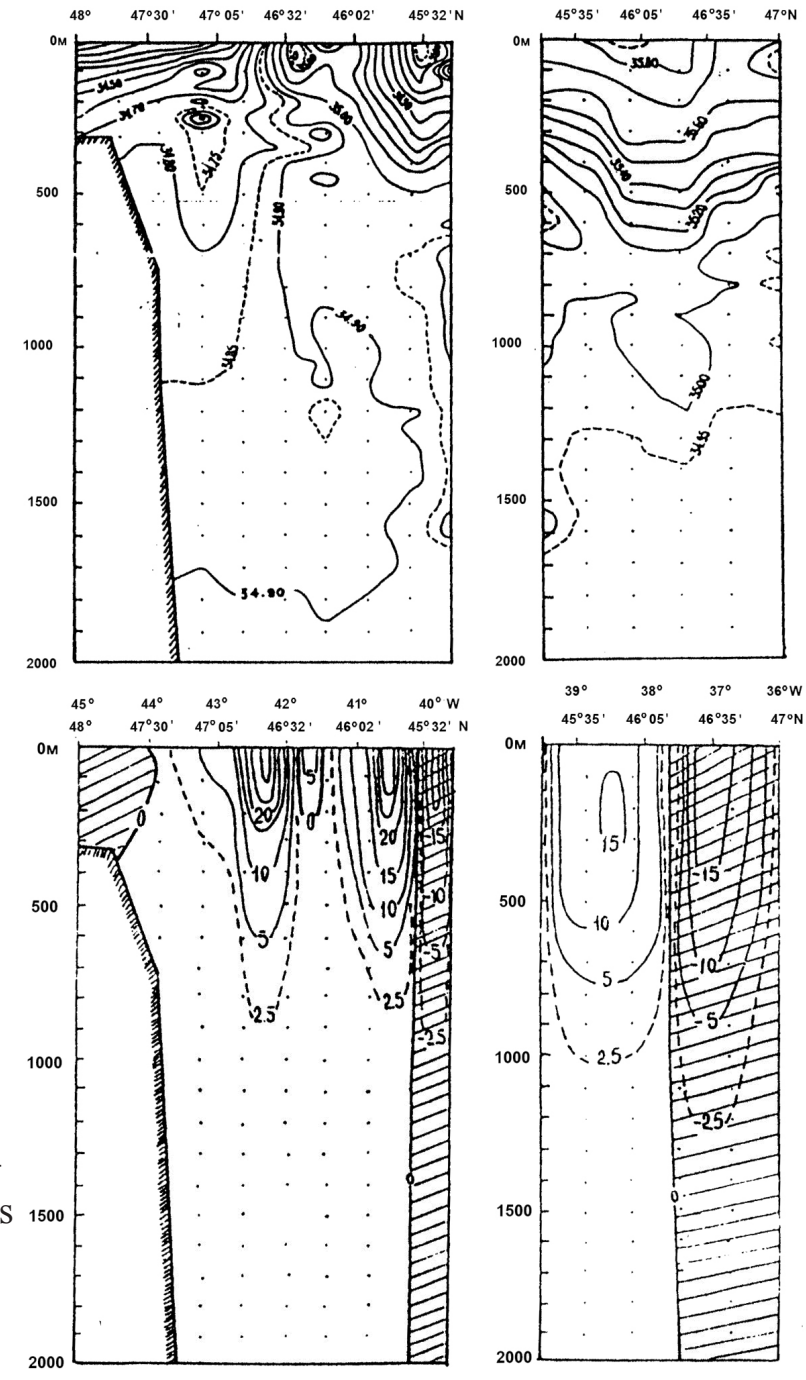

Fig. 6. XBT observations at section IV (May, 25-26), CTD sections V (May, 2628) and VI (May, 28-29). Section locations 150 are shown in Fig. 3 and explanations are given in Fig. 4. 
Cap. The temperature of the shelf waters here is $2-4^{\circ} \mathrm{C}$ and the salinity is smaller than 34.5 PSU. The SST sharp increase from $4^{\circ}$ to $7-7.5^{\circ} \mathrm{C}$ East of the continental slope $\left(43.5^{\circ} \mathrm{W}\right)$ may be identified as a front of the Northern Branch of the NAC. Its position here is approximately the same as on the Dietrich scheme (1975) (shown with a dotted line in Fig. 1). The front clearly manifests itself in the temperature distribution, but it is not seen in the salinity distribution.

The zone between $42^{\circ}$ and $43^{\circ} \mathrm{W}$ with the largest gradients of the SST (from $6-7^{\circ} \mathrm{C}$ to $14-15^{\circ} \mathrm{C}$ ) and large temperature and salinity gradients in the water column is evidently a zone of the Polar Front. At the sea surface and in the surface layers, this front is well marked by the 35 PSU salinity. The strong geostrophic flow here, directed into the picture in Fig. $6(\sim 34 \mathrm{~cm} / \mathrm{s})$ should be identified with the NAC or more correctly with its Central Branch. The cold water upwelling between this front and the next one near $40.5^{\circ} \mathrm{W}$ is seen in Fig. 6. Unfortunately, our data are not sufficient to determine whether it is a closed eddy or a NAC meander (Fig. 7). We identify the strong Northeastern geostrophic flow between $40^{\circ} \mathrm{W}$ and $41^{\circ} \mathrm{W}(\sim 32 \mathrm{~cm} / \mathrm{s})$ with a Southern Branch of the NAC. Note, that temperature and salinity distributions in the region of the Southern Branch of the NAC at section $\mathrm{V}$ and at the section along the $36^{\circ} \mathrm{W}$ meridian (Fig. 4) are similar. In both cases a salinity of 35.5 PSU quite well marks these streams at the surface layer.

High temperature and salinity show that the area along section $\mathrm{V}$ was occupied by the North Atlantic Central Water. The temperature and salinity distributions are rather

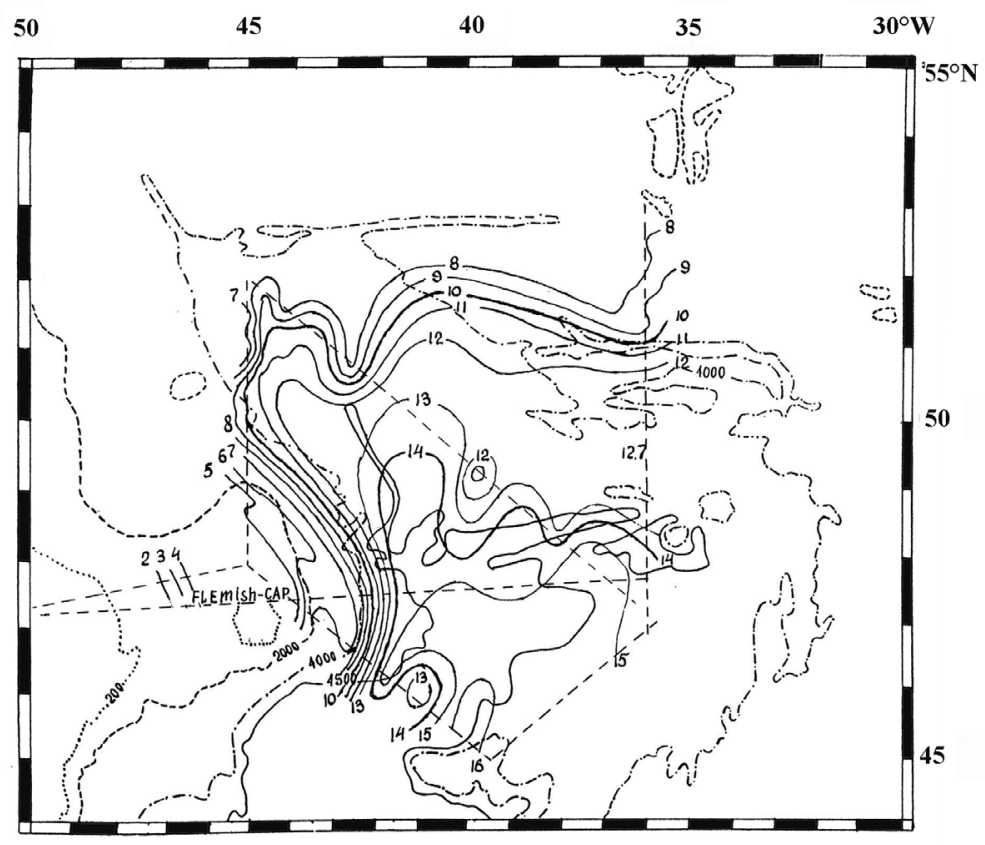

Fig. 7. The SST chart based on the observations over hydrographic sections carried out during the periods May 22-24 and May 25-June 11 (see Figs. 3a, b).

smooth. West of the $37.5^{\circ} \mathrm{W}$ the geostrophic flow is directed into the figure. East of this longitude, the return flow is observed. The latter may be identified with the recirculation of the Southern Branch of the NAC.

In Fig. 6 the locations of the CBNAC and the SBNAC are well indicated by the $10^{\circ} \mathrm{C}$ and $14^{\circ} \mathrm{C} \mathrm{SST}$ isotherms, respectively. The $\Delta T=0.20^{\circ} \mathrm{C}$ amounted for about $2^{\circ}$ west 
of $43^{\circ} \mathrm{W}$, but was less than $1{ }^{\circ} \mathrm{C}$ East of this meridian. At all other sections $\Delta T=0.20^{\circ} \mathrm{C}$ was also usually less than $1^{\circ} \mathrm{C}$, thus the summer heating does not appear to be a mask for the manifestation of the subsurface circulation at the sea surface in the observation period.

Sections VIII and IX. Section VIII (June, 7-10) was occupied approximately along the Labrador Basin axis (Fig. 3). The temperature and salinity distribution over this section (Fig. 8) indicate the existence of many circulation peculiarities (waves, meanders, eddies), but the data available are not sufficient for their proper identification. Some of the isotherms on the SST chart (Fig. 7) may be drawn differently. The Polar Front seems to cross the VIII section near $42^{\circ} \mathrm{W}$. At this longitude the SST and the surface salinity change from $8^{\circ}$ to $13^{\circ} \mathrm{C}$ and from 34.8 to $35.4 \mathrm{PSU}$, respectively; the dynamic velocities of the flow into this figure are as high as $30 \mathrm{~cm} / \mathrm{s}$. This flow is evidently the Central Branch of the NAC. Near $39.5^{\circ} \mathrm{W}$, the SST and the surface salinity increase from 10.5 to $14.5^{\circ} \mathrm{C}$ and from 35.10 to $35.60 \mathrm{PSU}$, respectively. There is another relatively strong geostrophic flow directed into the section, which may be interpreted as the Southern Branch of the NAC. West of each of these two flows, there are distinct return flows, which are seen in Fig. 8. The smaller SST decreases are relatively weak, and the return flows are also seen in this figure near $38^{\circ} \mathrm{W}$ and $44^{\circ} \mathrm{W}$. They can be induced by the eddies and meanders mentioned above.

Sea surface temperature decreases from 11 to $6-7^{\circ} \mathrm{C}$, and salinity decreases from 35.2 to 34.8 PSU over section IX to the North and South of $50.5^{\circ} \mathrm{N}$. Hence, the Eastward and westward geostrophic flows were observed directed to the North and South of this latitude, respectively. The possible cause of small dynamic velocities is the large intervals between CTD stations over this section. The $10^{\circ} \mathrm{C}$ surface isotherm and 35.0 PSU salinity seem to be good indicators of the Central Branch of the NAC over all other sections. Taking this into account we can suppose that at the time of observations section IX crossed the Central Branch of the NAC twice, first during the motion along the section to the returning point in the Northwest Corner (located west of the section) and second during the backward motion in the opposite direction (Fig. 7). Besides the Central Branch of the NAC, the thermal front related to the Northern Branch of the NAC may be observed at this section near $49^{\circ} \mathrm{N}$. The SST changes from 4 to $6^{\circ} \mathrm{C}$ at the front. The shelf waters with the temperature of about $3^{\circ} \mathrm{C}$ at a depth of 100-300 m located over the Flemish Cap area are limited by this front from the North.

Sections XI, XII, XVI. The XBT section XI (Fig. 9) follows the path of section IV (Fig. 6). During a period of two weeks between these two sections the surface temperature increased approximately by $1{ }^{\circ} \mathrm{C}$ and the secondary Arctic Front displaced to the west approximately by a half degree of longitude. The SST changed at this front from $1-4^{\circ}$ to $2-5^{\circ} \mathrm{C}$. The subsurface temperature of the Labrador Current Water over the Great Banks was equal to $-1^{\circ} \mathrm{C}$ and the temperature of the shelf waters over the Flemish Cap area, which ranged within $2-3^{\circ} \mathrm{C}$, remained practically unchanged. At the Eastern boundary of the shelf waters the increase in the SST from 5 to $7^{\circ} \mathrm{C}$ indicated the thermal front of the Northern Branch of the NAC. The Central Branch of the NAC was found at $48^{\circ} \mathrm{N}$ near $42.5^{\circ} \mathrm{W}$, where the strong Northward geostrophic flow $(60-80 \mathrm{~cm} / \mathrm{s})$ was observed 

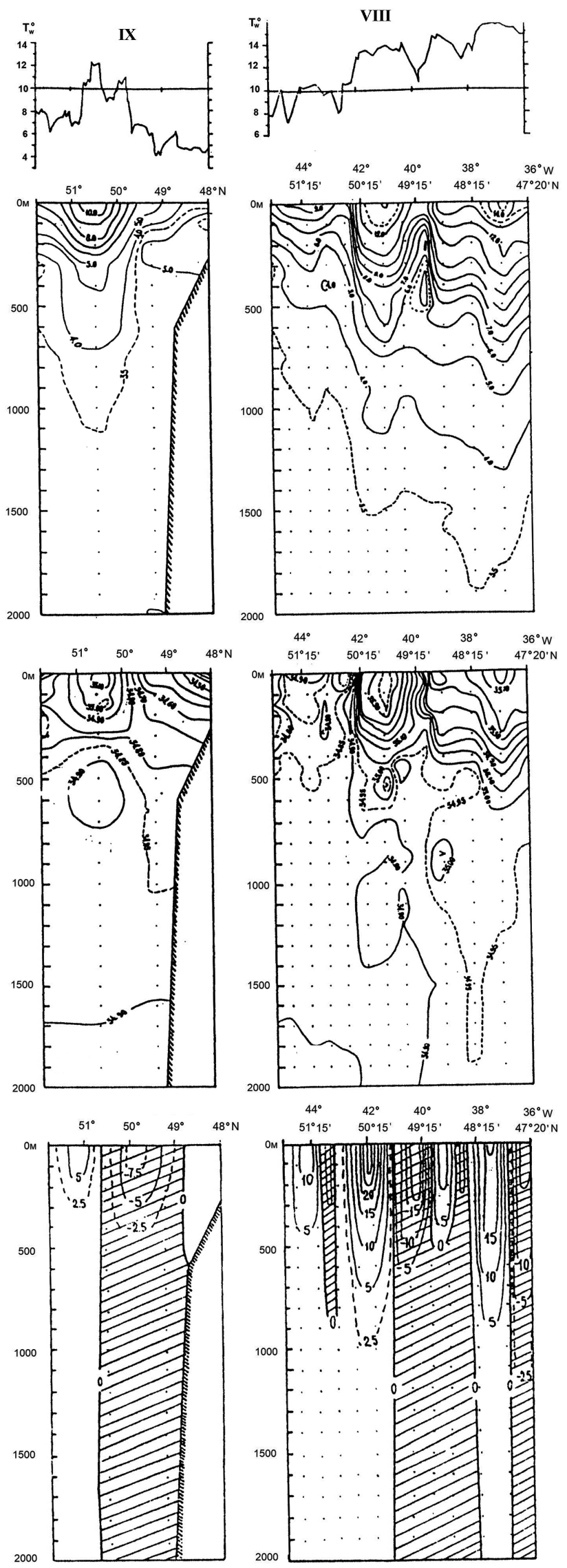

Fig. 8. Results of observations at CTD sections VIII (June, 7-10) and IX (June, 10-11). Section locations are shown in Fig. 3 and explanations are given in Fig. 4. 
Ivanov Yu.A. et al.
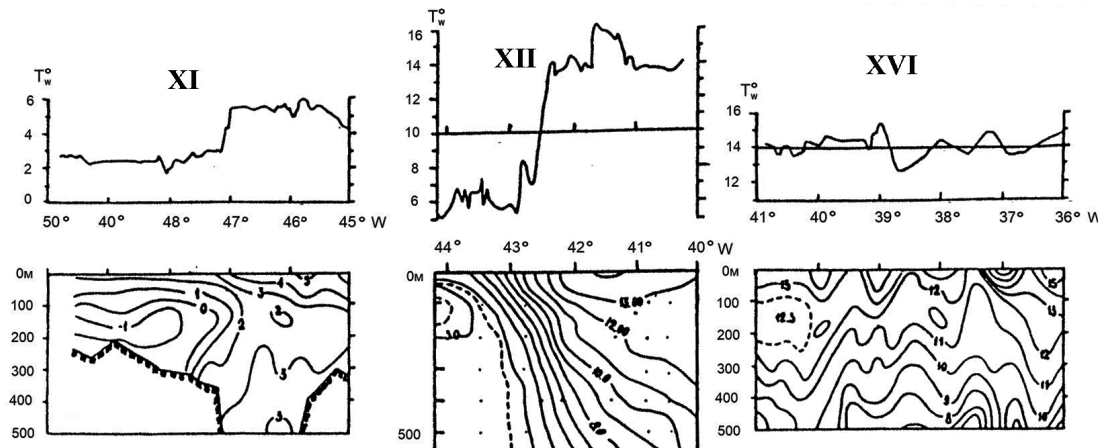

200
300
400
500
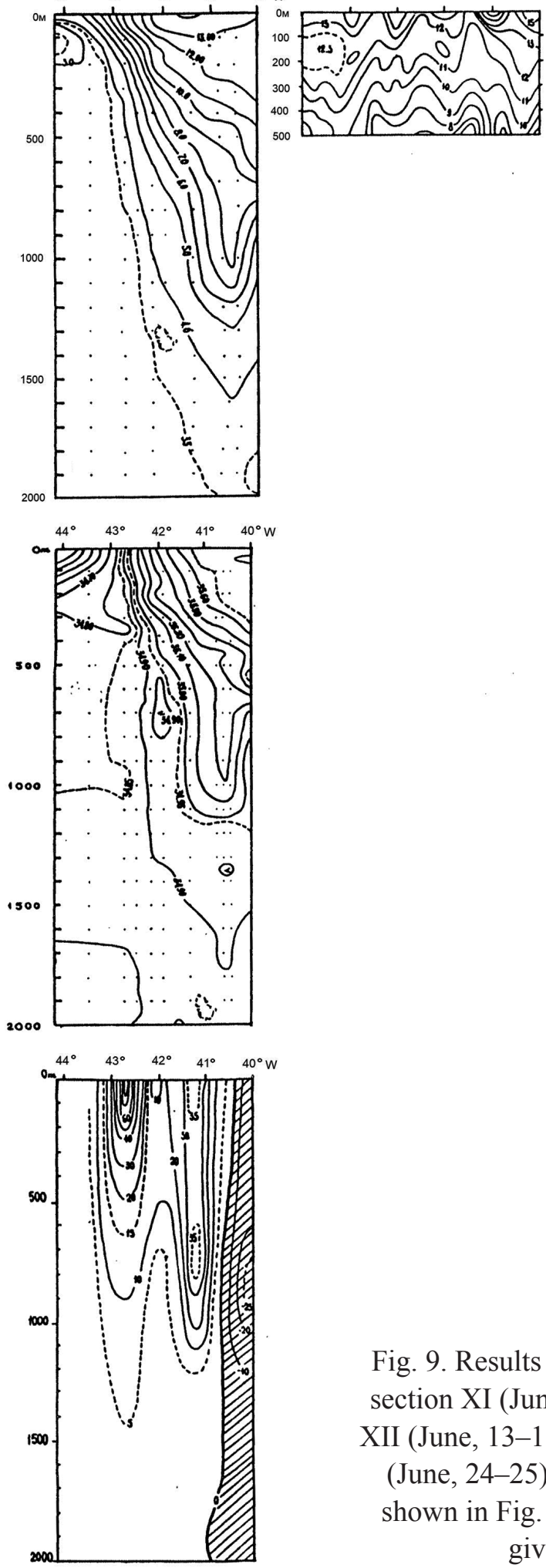

Fig. 9. Results of observations at XBT section XI (June, 12-13), CTD section XII (June, 13-15) and XBT section XVI (June, 24-25). Section locations are shown in Fig. 3 and explanations are given in Fig. 4. 
(Fig. 9). At this front the SST changed from 6 to $14^{\circ} \mathrm{C}$. We suppose that the secondary Northward flow observed at this latitude near the $41.5^{\circ} \mathrm{W}$ was the Southern Branch of the NAC as far as the sea surface salinity here was typical for this branch and was equal to 35.5 PSU. The SST changed at this front from 13.8 to $16^{\circ} \mathrm{C}$. Note also that there is a return flow near the $40^{\circ} \mathrm{W}$.

Warm waters with the surface temperature approaching $14^{\circ} \mathrm{C}$ with small wavelike oscillations in the isotherm distribution were observed over XBT section XVI. The temperature distribution along $48^{\circ} \mathrm{N}$ over XBT sections III and X (no figures) did not differ significantly from the one shown in Fig. 9 (see Fig. 3 for the locations of sections III and X).

Sections XIII and XIV. The XBT section XIII follows partly the path of section VIII (Fig. 3). The water temperature distribution here (Fig. 10) is similar to the one measured at section VIII (Fig. 8). In both cases the Polar Front is observed near $42^{\circ} \mathrm{W}$, where SST increases from 8 to $13^{\circ} \mathrm{C}$. A temperature minimum near $40^{\circ} \mathrm{W}$, which is supposedly associated with the cold eddy, is observed over both of these sections. Only minor changes in the SST distribution can be seen at the western edge of the section. The relatively cold Labrador Sea Water was observed at the Northernmost section XIV (Fig. 10). The temperature distribution was rather smooth here. The SST decreased gradually from $9-10^{\circ} \mathrm{C}$ in the Southwestern part of this section to $7-8^{\circ} \mathrm{C}$ in its Northeastern part. Small oscillations of isotherms are seen along this section.
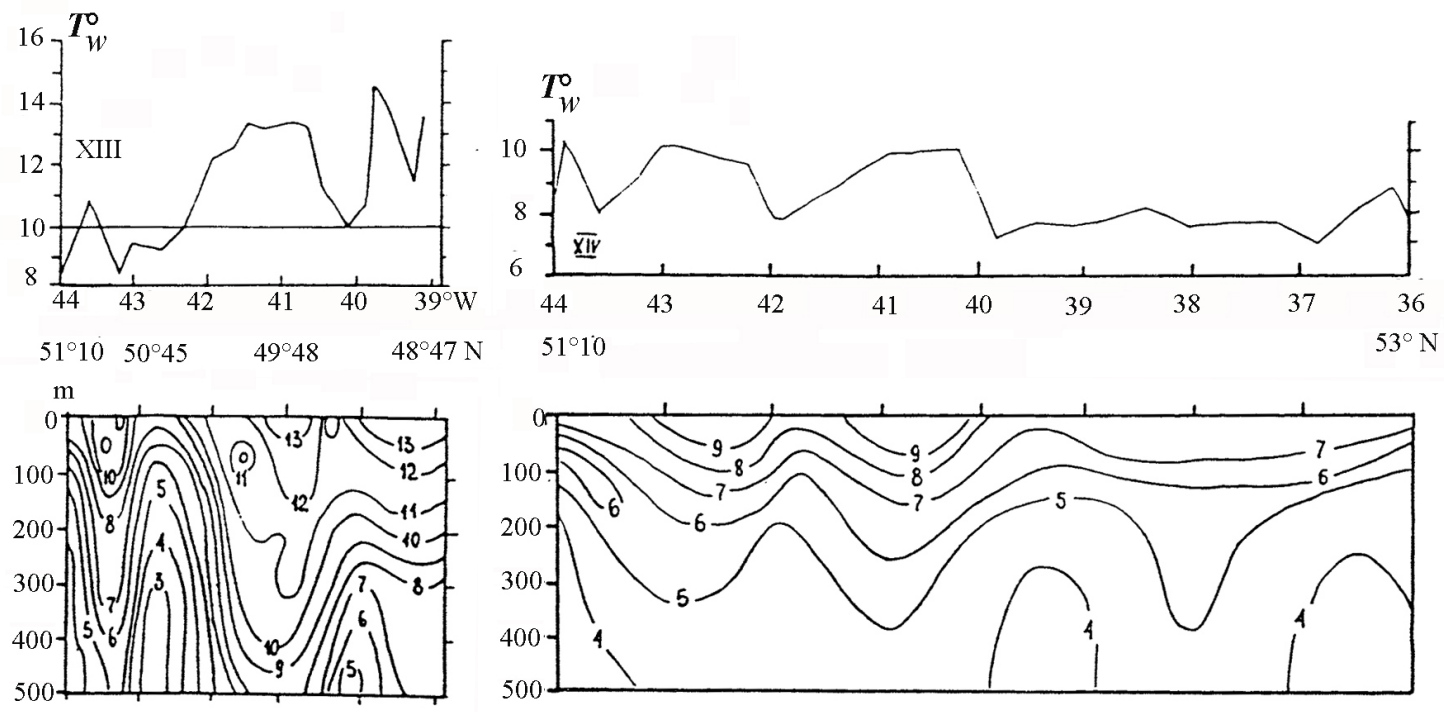

Fig. 10. Observations over XBT sections XIII (June, 16-17) and XIV (June, 17-18). Section locations are shown in Fig. 3 and explanations are given in Fig. 4.

The SST charts. As it was already shown, the summer heating of the upper ocean layer was not strong enough to mask the subsurface structure of the ocean during our observations. We believe that the sea surface temperature distribution on the charts (Fig. 7 and 11) correctly reflects this structure and the circulation pattern.

A two-jet structure of the NAC is observed over the sections occupied South of $48^{\circ} \mathrm{N}$. However, these jets do not diverge very far from each other. The final separation 


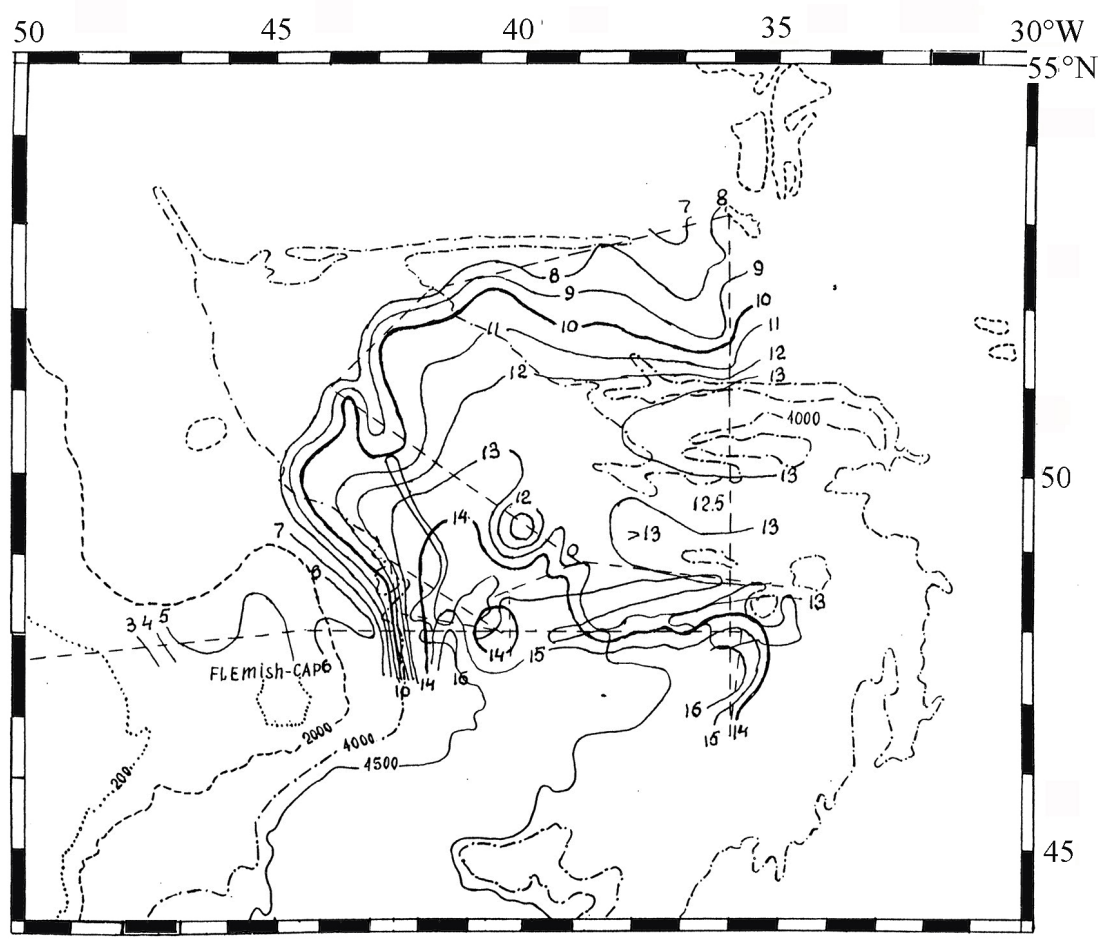

Fig. 11. The SST chart prepared on the basis of observations over hydrographic sections carried out during the period of June 11-30 (see Fig. 3c).

of the NAC branches occurs North of this latitude at a depth of $4500 \mathrm{~m}$ isobath, after producing a long narrow stream directed to the North; it turns to the East approximately normal to the $4000 \mathrm{~m}$ isobath (Figs. 7 and 11). The thermal front of the Central Branch of the NAC stretches to the North-Northwest along the $4000 \mathrm{~m}$ isobath up to the $50-51^{\circ} \mathrm{N}$, then turns to the East, crosses the $36^{\circ} \mathrm{W}$ meridian near the $51-52^{\circ} \mathrm{N}$ and finally turns sharply to the Northeast. The front of the Southern Branch of the NAC follows roughly the $4500 \mathrm{~m}$ isobath. It crosses $36^{\circ} \mathrm{W}$ near $48-49^{\circ} \mathrm{N}$ and then turns to the South-Southwest. Judging by the temperature distribution on the SST charts we can suppose, that besides the isobath divergence, cold and warm eddies that exist in abundance in the middle of the Labrador Basin, can significantly influence the NAC splitting in this region. The same eddies can produce the homogeneous surface waters $\left(12.5-13^{\circ} \mathrm{C}\right)$ observed in the wide zone between the Central and the Southern branches of the NAC East of $40^{\circ} \mathrm{W}$.

Several different versions of the SST charts could be drawn using the same data from our widely spaced hydrographic sections. Note also that to prepare SST charts we used the data collected during a relatively long period of 18-20 days. In the next section of our paper we will analyze the spatial and short-term temporal variations of different NAC branches using facsimile SST charts. As it was shown earlier, the $10^{\circ} \mathrm{C}$ isotherm is very informative to indicate the midstream of the Central Branch of the NAC. In addition, the $14^{\circ} \mathrm{C}$ isotherm can also serve as an indicator of the Southern Branch of the NAC at East in June 1990. 


\section{The NAC branches on the facsimile SST chart}

In cruise 50th of the R/V "Akademik Kurchatov" the facsimile SST charts of the North Atlantic were received from 5 meteorological centers: Halifax, Moscow, Offenbach, Bracknell, and Northwood. All of these charts provide an accuracy of approximately $1{ }^{\circ} \mathrm{C}$ (Romanov et al., 1991). The Halifax charts were selected as the priority charts for our study because of their largest scale. Also Halifax is the centre closest to the study area, and we suppose that SST charts produced in this centre are of better quality because of their better knowledge of the local circulation. These charts are transmitted twice a week (Tuesday and Friday). An example of the chart along with the scheme of hydrological fronts drawn following Baranov (1988) is presented in Fig. 12.

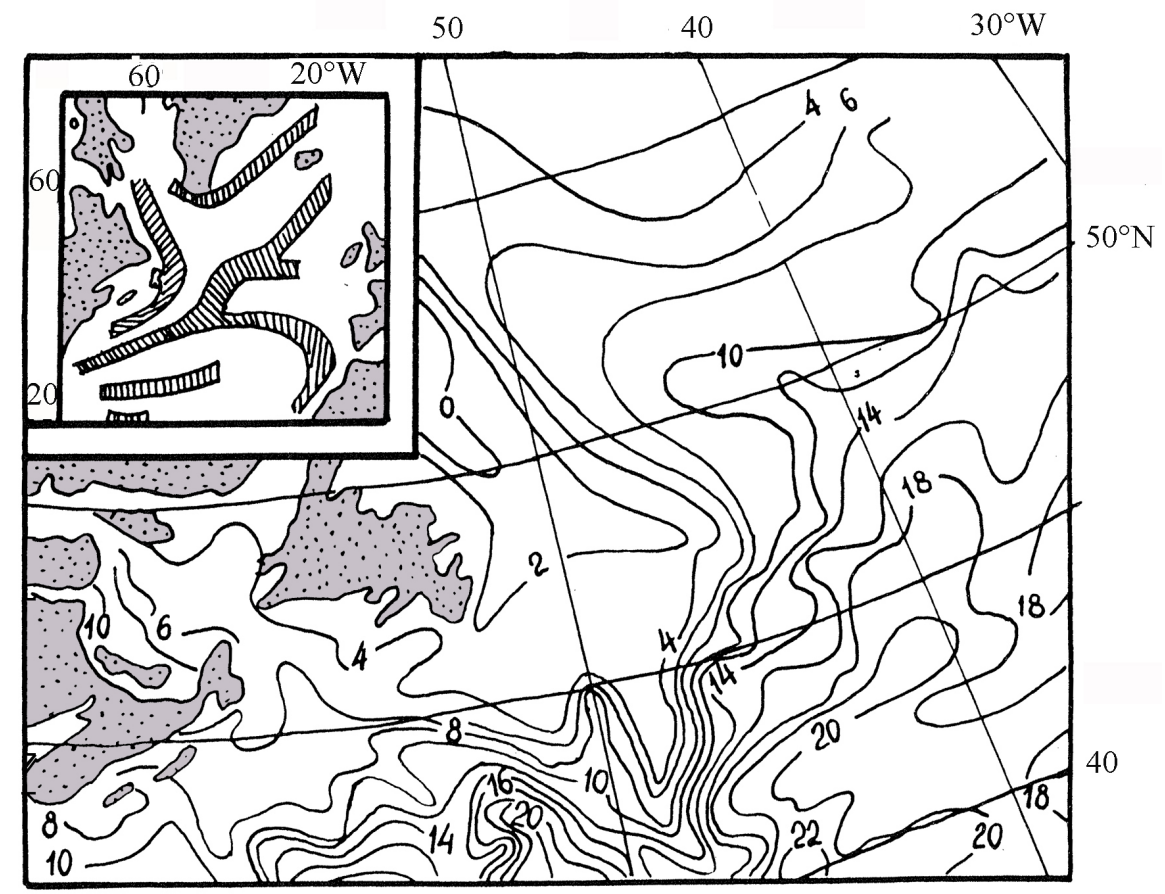

Fig. 12. Facsimile SST chart on June 12, 1990 (Halifax). A scheme of hydrological fronts from the paper by Baranov (1988) is shown in the upper left corner.

A detailed analysis of the Halifax charts revealed that in general it is hardly possible to apply these charts for the precise determination of the location of fronts based on the analysis of convergence of isotherms. This is due to the smoothness of these charts and because the isotherms are drawn only with $2^{\circ} \mathrm{C}$ intervals. It should be noted that in spite of the aforesaid the data on the location of those isotherms, which are shown on the Halifax charts are quite reliable. Thus, we hope that the form and variations of the 10 and $14^{\circ} \mathrm{C}$ isotherms on these charts (Fig. 13) can provide us with information concerning the spatial and temporal variability of the Central and Southern branches of the NAC within the region of observations. 

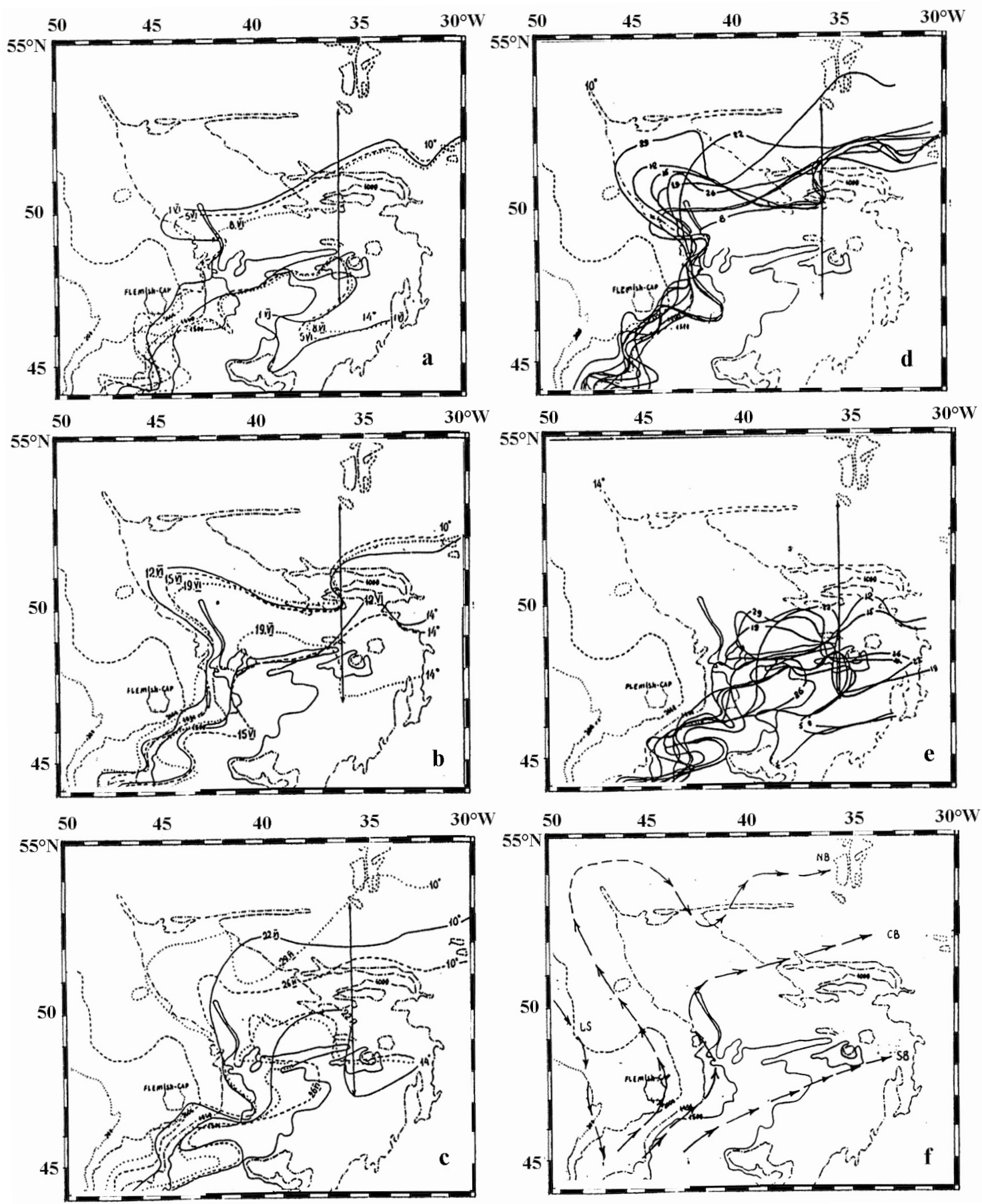

Fig. 13. Daily positions of the $10^{\circ}$ and $14^{\circ} \mathrm{C}$ SST isotherms in June, 1990 (a-e); mean locations of the $2^{\circ}, 6^{\circ}, 10^{\circ} \mathrm{C}$, and $14^{\circ} \mathrm{C} \mathrm{SST}$ isotherms in June 1990 (f).

A high correlation between the bottom topography and the variations in the $10^{\circ}$ and $14^{\circ} \mathrm{C}$ isotherms is seen in these charts. South of $48^{\circ} \mathrm{N}$, in the regions with a steep continental slope, in particular near $46^{\circ} \mathrm{N}$, the $10^{\circ}$ and $14^{\circ} \mathrm{C}$ isotherms approach close to each other. On the contrary, they diverge and form a meander at $44^{\circ}-45^{\circ} \mathrm{N}$ and near $48^{\circ} \mathrm{N}$, i.e., in the regions where the slope becomes smoother. Figures 7 and 11 show that the final separation of these two isotherms occurs usually North of $47.5-48^{\circ} \mathrm{N}$. In only one case (June 22), the splitting was observed farther to the South at $46.5^{\circ} \mathrm{N}$. 
Strong fluctuation of the Northern Branch of the NAC $\left(10^{\circ} \mathrm{C}\right.$ isotherm $)$ is observed over the Labrador Basin (Fig. 13d). In June 1990, it changed its location from the Northwestern edge of the basin on June 29 to the Southeast edge on June 8. The observed peculiarity is supported by the results of current measurements made by Lasier (1994) in the Northwestern Corner. He also found significant fluctuations of the Northern Branch of the NAC. It should be noted, that similar fluctuations of the Central Branch of the NAC can produce the sea temperature anomalies frequently observed in this region (Byshev et al., 1993).

Excluding the data only on June 29 , the $10^{\circ} \mathrm{C}$ isotherm crossed the $35^{\circ} \mathrm{W}$ meridian between $51^{\circ}$ and $52^{\circ} \mathrm{N}$ (Fig. 13d). However, on some days, the $10^{\circ} \mathrm{C}$ isotherm first approaches close to the $36^{\circ} \mathrm{W}$ meridian near $50^{\circ} \mathrm{N}$, then turns to the North-Northwest, and near $51.5^{\circ} \mathrm{N}$ it turns again to the East. Here the isotherms merge and directly tend to this latitude. The Southern Branch of the NAC undergoes fluctuations in this region, which are even stronger than in the region of the Central Branch. On June 12 and 15, the $14^{\circ} \mathrm{C}$ isotherm was elongated in the Eastern-Northeast direction North of $48^{\circ} \mathrm{N}$ (Fig. 13b). In all other cases it turns to the South-Southwest near $36^{\circ} \mathrm{W}$ and forms a meander there. A relatively small meander was found on June 19, 26, and 29. On June 1, 5 , and 8 , the meander was strongly extended to the Southwest as it was observed earlier by Krauss et al., (1987) (Fig. 2).

It is possible that two jets of the Southern Branch exist here simultaneously. The first jet crosses the $36^{\circ} \mathrm{W}$ directly and the second one forms a meander here. However, only one of these jets can be identified in the SST distribution. Figure $13 \mathrm{f}$ shows the mean position of the $2,6,10$, and $14^{\circ} \mathrm{C}$ isotherms (supposedly associated with the Labrador Current and the Northern, Central, and Southern branches of the NAC, respectively) in June 1990; however they do not give us the idea of the very complicated ocean circulation here.

\section{The current measurements on $360^{\circ} \mathrm{W}$}

The time interval between current velocity measurements on moorings was 5 minutes. Prior to the analysis of the zonal $u$ and meridional $v$ velocity components were smoothed using a Tukey filter:

$$
\tilde{u}, \tilde{v}(i)=\frac{1}{l} \sum_{j=i-l / 2}^{j=i+l / 2}\{u, v(j) \cdot[1+\cos (2 \pi(j-i) / l)]\} .
$$

Filter parameter $l$ equal to 420 was accepted to achieve the effective smoothing of $u$ and $v$ components over a period of 35 hours. This period is sufficient for filtering out the inertial and tidal oscillations.

The main features of the ocean circulation in the region shown in Fig. 14 agree well with the structure of the geostrophic flows at this section (Fig. 4). Two strong Eastward streams, same as in Fig. 4, are seen in Fig. 14. The velocity of the first one located near $51^{\circ} \mathrm{N}$ is approximately $40 \mathrm{~cm} / \mathrm{s}$; it is directed to the Northeast. The other stream observed at $48^{\circ} \mathrm{N}$ is directed to the SouthEast and its velocity is almost $50 \mathrm{~cm} / \mathrm{s}$. In both streams the current velocities are decreasing from the surface to the deeper layers.

Observations made at the $36^{\circ} \mathrm{W}$ meridian show the existence of intense meridional components of streams comparable in magnitude to the zonal components. North of $49^{\circ} \mathrm{N}$, these components are directed Northward; South of $49^{\circ} \mathrm{N}$, their direction changes to the 


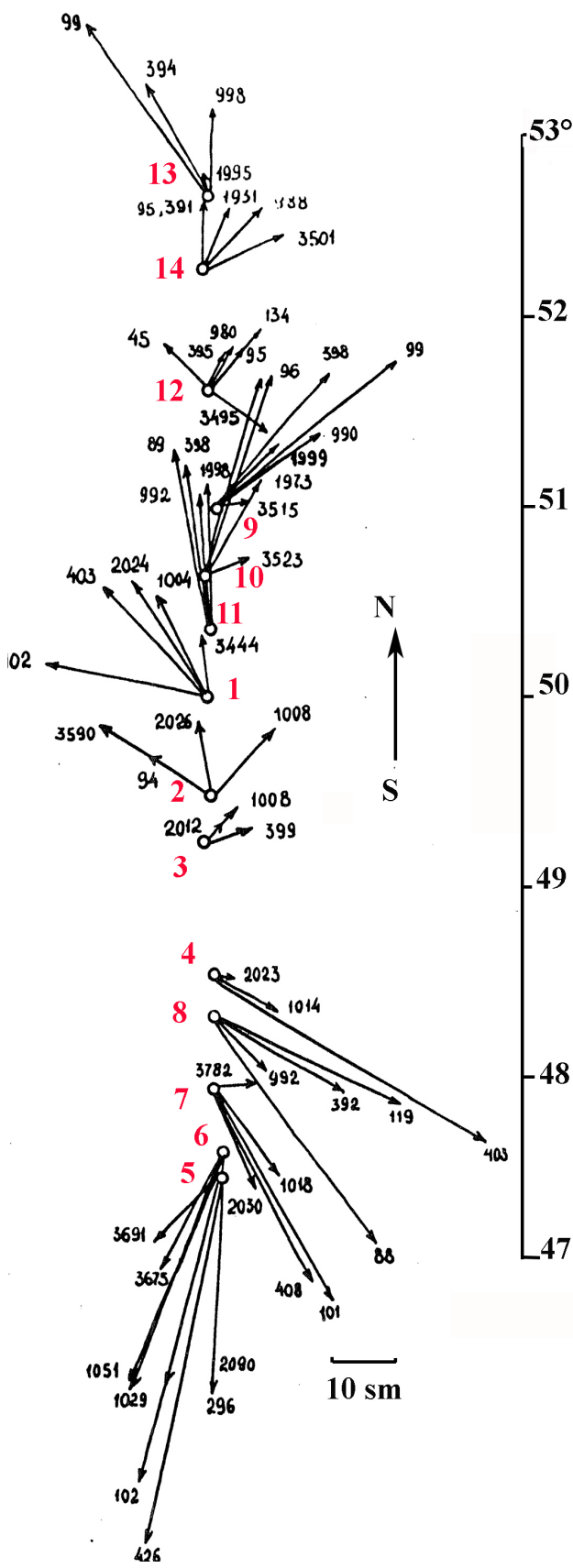

Fig. 14. Hodographs of the current velocity vectors averaged over the periods of observations (see Table 1) for

14 moorings at the $36^{\circ} \mathrm{W}$ meridian.
Southward, which agrees with the characteristic isotherm pattern (Fig. 13). This interesting fact will be explained below. The velocities of the return westward flows near $47.5^{\circ} \mathrm{N}, 50^{\circ} \mathrm{N}$, and $53^{\circ} \mathrm{N}$ are close to those of the Eastward flows. Note that hodographs (Fig. 14) are not quite comparable with each other because of the different periods of observations performed at different moorings (see Table 1).

Along the $36^{\circ} \mathrm{W}$ meridian, the Southern Branch of the NAC keeps its location close to $48^{\circ} \mathrm{N}$ throughout the water column from $100 \mathrm{~m}$ to $3500 \mathrm{~m}$ (Fig. 15) during the whole period of observations from June 2 to June 22. The stream was of about $60-80$ miles wide with current velocities equal to $30-70 \mathrm{~cm} / \mathrm{s}$ at $100 \mathrm{~m}$ and about $10 \mathrm{~cm} / \mathrm{s}$ at $3500 \mathrm{~m}$. Day to day variations of the velocity vectors in the region of this branch of the NAC closely correspond to the $14^{\circ} \mathrm{C}$ sea surface isotherm variations (Fig. 13). During the first period of observations, from June 5 to June 8 , this isotherm crossed the $36^{\circ} \mathrm{W}$ meridian near $48.5^{\circ} \mathrm{N}$. Then, it turned to the South-Southwest and crossed this meridian again in the opposite direction. Similar variations in the current velocity vectors are seen in Fig. 15. During the next period, from June 12 to June 15 a large meander detected by the $14^{\circ} \mathrm{C}$ isotherm disappeared, although it was observed earlier in the Southeastern part of the Newfoundland Basin. We suppose that this occurred because of its collapse. In these cases, the $14^{\circ} \mathrm{C}$ isotherm crosses the $36^{\circ} \mathrm{W}$ meridian near $49^{\circ} \mathrm{N}$ heading directly to the Northeast. The strong weakening of the currents observed in the zone of the Southern Branch of the NAC at $36^{\circ} \mathrm{W}$ in this period can be explained by the collapse of this meander. From June 18 to 22 , the $14^{\circ} \mathrm{C}$ isotherm meander appeared again near $36^{\circ} \mathrm{W}$. The velocity vectors during this period reveal two Eastward flows near $49.5^{\circ} \mathrm{N}$ and near $47.5-48^{\circ} \mathrm{N}$ with a westward flow between them (seen at 1000 and $2000 \mathrm{~m}$ ), which agrees well with the meander configuration. Unfortunately, the current meters at $100 \mathrm{~m}$ and $400 \mathrm{~m}$ on mooring No. 4 were out of order during this period. Thus, we were unable to confirm the existence of the westward flow at these levels. 
The Central Branch of the NAC, as seen in Fig. 15, is a Northeastward stream of about $60-80$ miles wide. It crossed the $36^{\circ} \mathrm{W}$ meridian near $51^{\circ} \mathrm{N}$ and near $51.5^{\circ} \mathrm{N}$ in the beginning and in the end of the period of observations, respectively. The current velocities recorded in its midstream in the upper layer $(30-50 \mathrm{~cm} / \mathrm{s})$ are approximately $10-20 \mathrm{~cm} / \mathrm{s}$ less than those measured in the Southern Branch of the NAC. The location of this branch remains practically unchanged down to $2000 \mathrm{~m}$. Some of the changes in its position in the deeper layers may be caused by the influence of the local bottom topography. The velocity vectors during this period were directed to the North-Northwest between $50^{\circ}$ and $51^{\circ} \mathrm{N}$ and near $51.5^{\circ} \mathrm{N}$ they turned to the Northeast based on the $10^{\circ} \mathrm{C}$ isotherm pattern observed from June 8 to 19.

Table 1. Presents the statistics of the properties of currents based on the mooring measurements deployed along $36^{\circ} \mathrm{W}$.

\begin{tabular}{|c|c|c|c|c|c|c|c|c|c|c|}
\hline $\begin{array}{c}\text { Mooring } \\
\text { No. }\end{array}$ & $\begin{array}{c}\text { Latitude } \\
\text { North }\end{array}$ & $\begin{array}{c}\text { Longitude } \\
\text { West }\end{array}$ & $\begin{array}{c}\text { Depth, } \\
\mathrm{m}\end{array}$ & $\begin{array}{c}\text { Period of } \\
\text { observations }\end{array}$ & \multicolumn{2}{|c|}{$\begin{array}{c}\text { Duration, } \\
\text { days }\end{array}$} & \multicolumn{5}{|c|}{ Depths of observations, m } \\
\hline 1 & $50^{\circ} 01^{\prime}$ & $36^{\circ} 03^{\prime}$ & 4480 & $30.05-20.06$ & 22 & 102 & 403 & 1004 & 2024 & 3444 \\
\hline 2 & $49^{\circ} 32^{\prime}$ & $36^{\circ} 02^{\prime}$ & 4140 & $30.05-20.06$ & 22 & 94 & - & 1008 & 2026 & 3590 \\
\hline 3 & $49^{\circ} 12^{\prime}$ & $36^{\circ} 02^{\prime}$ & 4360 & $31.05-21.06$ & 22 & - & 399 & 1008 & 2012 & - \\
\hline 4 & $48^{\circ} 33^{\prime}$ & $35^{\circ} 46^{\prime}$ & 4570 & $31.05-21.06$ & 22 & - & 403 & 1014 & 2023 & - \\
\hline 5 & $47^{\circ} 22^{\prime}$ & $36^{\circ} 00^{\prime}$ & 4290 & $01.06-07.06$ & 7 & 99 & - & 1029 & 2058 & 3675 \\
\hline 6 & $47^{\circ} 26^{\prime}$ & $36^{\circ} 05^{\prime}$ & 4300 & $01.06-07.06$ & 7 & 102 & 426 & 1051 & 2090 & 3691 \\
\hline 7 & $47^{\circ} 55^{\prime}$ & $35^{\circ} 53^{\prime}$ & 4540 & $01.06-24.06$ & 24 & 101 & 408 & 1081 & 2030 & 3782 \\
\hline 8 & $48^{\circ} 20^{\prime}$ & $36^{\circ} 02^{\prime}$ & 4580 & $02.06-22.06$ & 21 & 88 & 392 & 991 & - & - \\
\hline 9 & $51^{\circ} 00^{\prime}$ & $36^{\circ} 00^{\prime}$ & 4320 & $04.06-19.06$ & 16 & 99 & 398 & 990 & 1999 & 3515 \\
\hline 10 & $50^{\circ} 41^{\prime}$ & $36^{\circ} 00^{\prime}$ & 4020 & $04.06-19.06$ & 16 & 96 & 399 & 992 & 1973 & 3523 \\
\hline 11 & $50^{\circ} 23^{\prime}$ & $36^{\circ} 03^{\prime}$ & 3840 & $04.06-20.06$ & 17 & 89 & 398 & 999 & 1988 & - \\
\hline 12 & $51^{\circ} 37^{\prime}$ & $35^{\circ} 55^{\prime}$ & 3920 & $05.06-19.06$ & 15 & 95 & 395 & 980 & 2025 & 3495 \\
\hline 13 & $52^{\circ} 47^{\prime}$ & $35^{\circ} 58^{\prime}$ & 3750 & $05.06-18.06$ & 14 & 99 & 394 & 998 & 1995 & - \\
\hline 14 & $52^{\circ} 18^{\prime}$ & $35^{\circ} 56^{\prime}$ & 3870 & $06.06-18.06$ & 13 & 95 & 391 & 988 & 1931 & 3501 \\
\hline
\end{tabular}

Note: indicates that data at corresponding depth level are missing.

It is interesting that the current weakening in the region of the Southern Branch of the NAC found on June 11 near $48^{\circ} \mathrm{N}$ was observed later in the Northern part of the region; on June 12-13, it was already noticed in the zone of the Central Branch of the NAC $\left(51^{\circ}-51.5^{\circ} \mathrm{N}\right)$.

Fig. $15 \mathrm{~b}$ shows that in June 1990 the stream structure at $36^{\circ} \mathrm{W}$ revealed no distinct variations from day to day. Its main features are also seen in the mean circulation pattern. As a rule, the main zonal flows consisting of two Eastward and three Westward flows propagated in the water column from $100 \mathrm{~m}$ to $3600 \mathrm{~m}$. The largest velocities were observed in the upper layers, at 100, and $400 \mathrm{~m}$. They decrease in deeper layers and slightly increase at some places near the bottom.

The meridional flows on June 6, 11, and 16 and the meridional flows averaged over the period of observations demonstrate a large-scale divergence over the section 

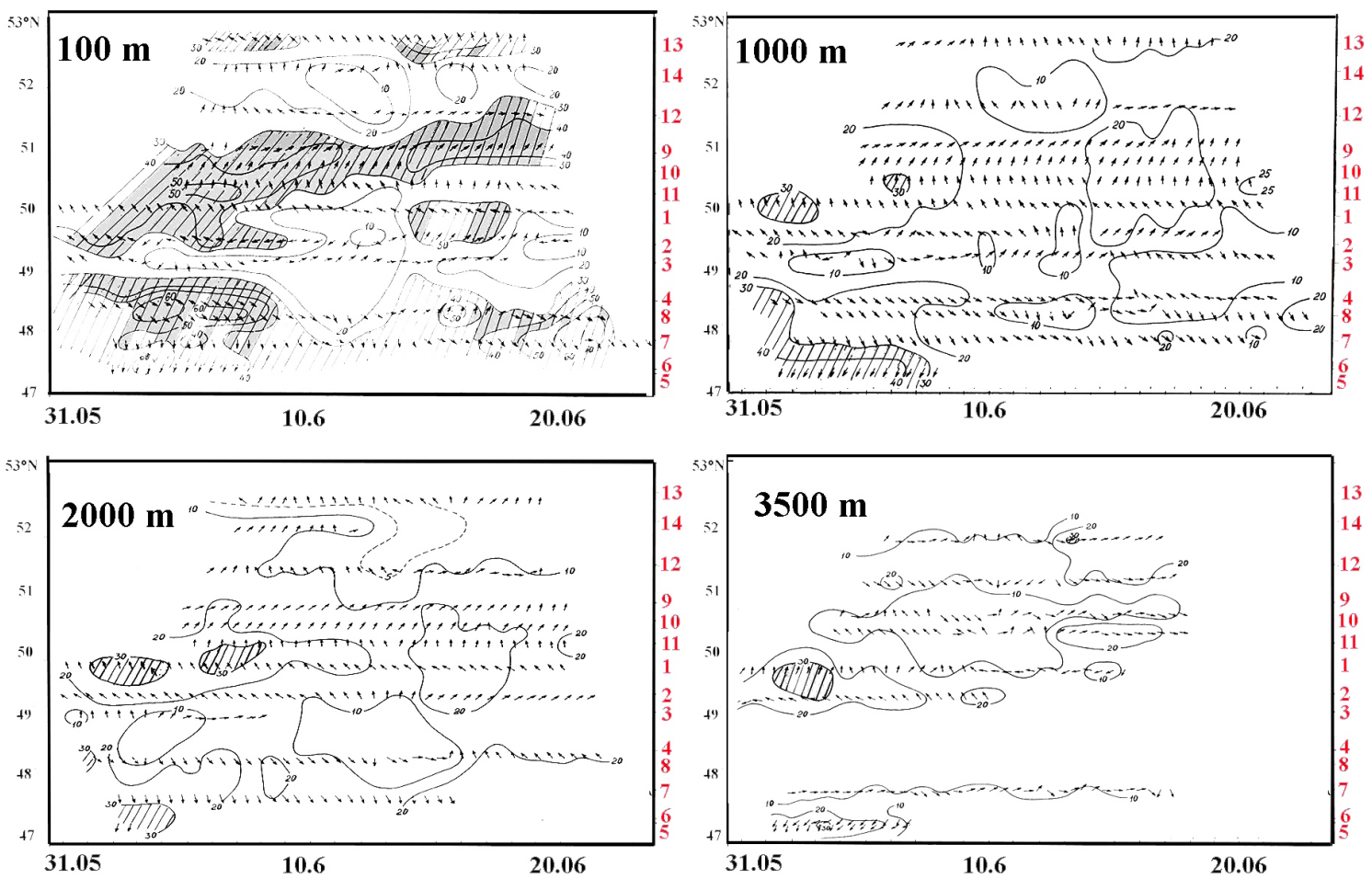

Fig. 15. Direction (vectors) and speed (isolines) in $\mathrm{cm} / \mathrm{s}$ of currents at 100, 1000, 2000, and $3500 \mathrm{~m}$ over the section along the $36^{\circ} \mathrm{W}$ meridian. Instrumental measurements data obtained in May-June 1990 were used. Vectors, pointing in the " $+y$ " direction correspond to the Northern direction of the flows. Numbers of moorings are shown at the right ordinate line. In the graph for $100 \mathrm{~m}$, the $400 \mathrm{~m}$ current velocities measured on moorings 3 and 4 are shown because of the lack of velocity data at $100 \mathrm{~m}$.

along $36^{\circ} \mathrm{W}$ with the Northward streams North of $49^{\circ} \mathrm{N}$ and Southward streams South of this latitude (Fig. 16). We also observed a slight tendency to the formation of a twolayer structure of the meridional streams with the flows near the bottom in the opposite direction to the flows in the remaining part of the water column.

Near $49^{\circ} \mathrm{N}, 36^{\circ} \mathrm{W}$ a seamount $(2600 \mathrm{~m})$ was found in cruise 50 of the $\mathrm{R} / \mathrm{V}$ "Akademik Kurchatov". According to the International Geological-Geophysical Atlas (1988-1989) there is a small bottom elevation in this region, which does not exceed a depth of $4000 \mathrm{~m}$ (Fig. 7). We believe that due to its East-Southeast orientation and the height, which is significantly shallower than $4000 \mathrm{~m}$, the found bottom elevation can play an important role in the formation of the local ocean circulation.

At the $36^{\circ} \mathrm{W}$ meridian, the Southern Branch of the NAC flows mainly to the South of the bottom elevation (Fig. 15). Near the elevation, the mean flow direction is EasternSouthEastern, and it is the same as the direction of the $4000 \mathrm{~m}$ isobath. East of $36^{\circ} \mathrm{W}$ one part of this branch turns to the South-Southwest. The second flow can continue in the Eastern-Southeast direction and the third flow (the Northern one), as we suppose, turns to the North round the Eastern side of the bottom elevation. At the Northern periphery of the bottom elevation, the Northern part of the Southern Branch of the NAC heads to the West-Northwest in accordance with the $4000 \mathrm{~m}$ isobath orientation converting into a 

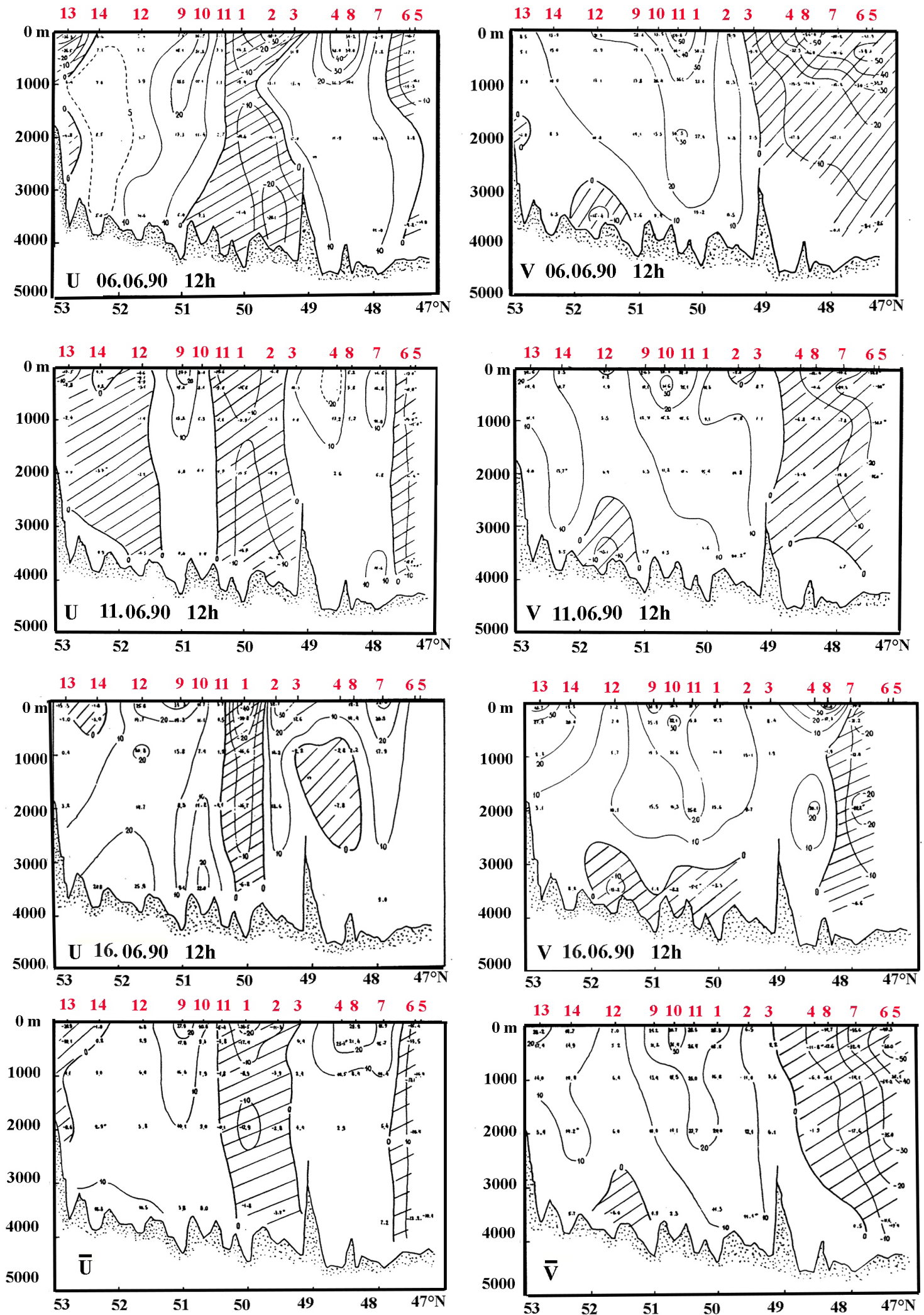

Fig. 16. Zonal (U) and meridional (V) flows in $\mathrm{cm} / \mathrm{s}$ over the section along the $36^{\circ} \mathrm{W}$ meridian derived from instrumental measurements on June 6,11 , and 16 and averaged $(\bar{U})$ and $(\bar{V})$ over the period of observations. The asterisk near the values of $u$ and $v$ at specific depths indicates that this value is normalized over the whole period of observations on this mooring using the measurements at the closest neighboring depth. 
return flow. It should be noted that the temperature and salinity characteristics of water masses are similar to those South and North of $49^{\circ} \mathrm{N}$, i.e., in the regions where direct and return flows are observed (Fig. 4). West of $36^{\circ} \mathrm{W}$, this return flow can meet the Central Branch of the NAC and give it an impulse to move Northward.

Future observations will hopefully make it clear if there is an anticlockwise flow to the East of the bottom elevation and whether the Central Branch of the NAC can be drawn into the Northward motion by the return flow.

It was shown earlier that the weakening of the Southern Branch of the NAC on June 11 , was seen in the region of the central return flow on the next day and in the region of the Central Branch of the NAC a day later. To our opinion, this fact can be explained by the Northward motion of water masses in the Northern part of the Southern Branch of the NAC.

The ocean circulation around the seamount is unstable (Fig. 17). Hence, the data over the long period of observations have to be collected to obtain a reliable pattern of the mean circulation in this region.

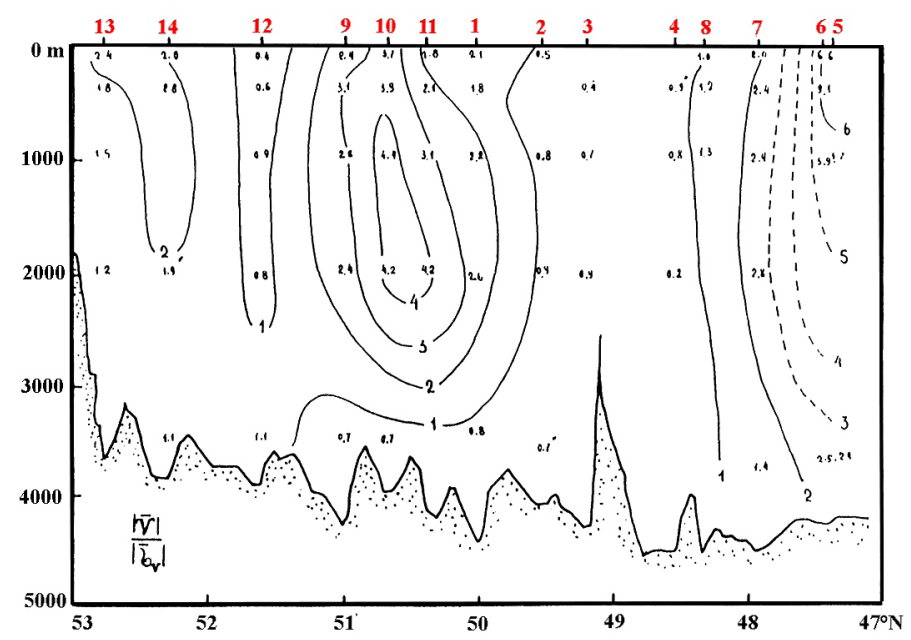

Fig. 17. Stability of the ocean circulation (-) over the section along the $36^{\circ} \mathrm{W}$ meridian.

The Central Branch of the NAC s characterized by the largest Eastward transport through the section along $36^{\circ} \mathrm{W}$. It varies from 25.3 to $127.4 \mathrm{~Sv}$; the mean value is $62.4 \mathrm{~Sv}$ (Table 2). These values are comparable with the results of Lazier (1994), who estimated the transport of the Central Branch of the NAC in the Northwest Corner equal to $50 \pm$ $23 \mathrm{~Sv}$. The mean transport of the Southern Branch of the NAC is smaller and equals to $48.7 \mathrm{~Sv}$. It is interesting that approximately the same mean value equal to $46.5 \mathrm{~Sv}$ is provided by the Central and Southern return flows together. These return flows are supposedly the Northern and Southern recirculations of the Southern Branch of the NAC. It does not leave much room for the formation of the Eastward flow from the Southern Branch of the NAC East of $36^{\circ} \mathrm{W}$. Unfortunately the data available do not give grounds to consider such a possibility with much confidence. There is lack of data at some depths on moorings 4 and 8 in the Southern Branch of the NAC. There is also a possibility that a part of the Southern return flow propagated South of our current meter section. 
Table 2. Zonal transport of the main streams through the current meter section along the $36^{\circ} \mathrm{W}$ meridian in June 1990 (in $10^{6} \mathrm{~m} / \mathrm{s}$ ) on the selected days (same as in Fig. 15) and the flow transport values averaged over the periods of observations at each of the moorings.

\begin{tabular}{|c|c|c|c|c|c|c|c|c|}
\hline Date & $\begin{array}{c}\text { Return } \\
\text { flow } \\
\text { North }\end{array}$ & $\begin{array}{c}\text { Central } \\
\text { Branch of } \\
\text { the NAC }\end{array}$ & $\begin{array}{c}\text { Central } \\
\text { flow } \\
\text { Central }\end{array}$ & $\begin{array}{c}\text { Southern } \\
\text { Branch } \\
\text { of the } \\
\text { NAC }\end{array}$ & $\begin{array}{c}\text { Return } \\
\text { flow } \\
\text { South }\end{array}$ & $\begin{array}{c}\text { Westward } \\
\text { flow total }\end{array}$ & $\begin{array}{c}\text { Eastward } \\
\text { flow total }\end{array}$ & $\begin{array}{c}\text { Resulting } \\
\text { transport }\end{array}$ \\
\hline June 06 & -4.1 & 70.5 & -54.9 & 95.6 & -6.0 & -65.0 & 166.1 & 101.1 \\
\hline June 11 & -24.9 & 23.5 & -42.0 & 49.1 & - & -67.0 & 75.2 & 7.8 \\
\hline June 16 & -2.0 & 127.4 & -24.7 & 74.0 & -8.0 & -34.6 & 201.4 & 166.8 \\
\hline average & -3.7 & 62.4 & -30.4 & 48.7 & -16.1 & -50.2 & 111.1 & 60.9 \\
\hline
\end{tabular}

Note: Positive and negative values refer to the Eastward and westward transport, respectively.

The transport of the Northern Return flow is small; it is equal to $3.7 \mathrm{~Sv}$. The total mean Eastward transport is as high as $111 \mathrm{~Sv}$; after the subtraction of the return flows the transport becomes 60.9 Sv. Note, that according to Byshev et al. (1993), the North Atlantic Current was characterized by anomalously high intensity in May-June, 1990; thus our estimates of the NAC transport in this period may also be greater than the mean value.

\section{Summary and conclusions}

In May-June, 1990 the R/V "Akademik Kurchatov" made several CTD and XBT sections crossing the main hydrological fronts in the Newfoundland energetically active zone $\left(45-53^{\circ} \mathrm{N}, 36-45^{\circ} \mathrm{W}\right)$. Sea surface temperature was recorded along all sections. Fourteen moorings were deployed along the $36^{\circ} \mathrm{W}$ meridian $\left(47-53^{\circ} \mathrm{N}\right)$ for an approximately one month period with current meters installed at 100, 400, 1000, 2000, and $3500 \mathrm{~m}$ depths. Facsimile SST charts of the North Atlantic were received by radio over the whole period of observations.

The analysis of these data shows that during the period of observations the two-jet structure of the NAC was manifested even South of $48^{\circ} \mathrm{N}$, although these jets did not diverge strongly from each other. At the locations of with relatively steep continental slope they approached closely to each other, however they diverge and can form a meander where the slope becomes less steep. The final NAC splitting into the Central and Southern branches takes place North of $47.5-48^{\circ} \mathrm{N}$, where the $4500 \mathrm{~m}$ isobath turns East approximately normal to the $4000 \mathrm{~m}$ isobath. There are some evidences that besides the divergence of the isobaths, the cold and warm eddies (found in abundance in the Labrador Basin) can play an important role in the NAC splitting here. The Central Branch of the NAC continues to the North-Northwest along the $4000 \mathrm{~m}$ isobath, turns to the East near $51^{\circ} \mathrm{N}$, crosses the $36^{\circ} \mathrm{W}$ meridian between $51^{\circ}$ and $52^{\circ} \mathrm{N}$ and then directs to the Charlie Gibbs Fracture Zone. Sometimes it comes close to $36^{\circ} \mathrm{W}$, first near $50^{\circ} \mathrm{N}$, than turns to the North-Northwest and finally turns to the East-Northeast near $51.5^{\circ} \mathrm{N}$. Strong fluctuations of the Central Branch of the NAC were observed in the Labrador Basin. The Southern Branch of the NAC follows approximately the $4500 \mathrm{~m}$ isobath and crosses the $36^{\circ} \mathrm{W}$ 
meridian near $48-49^{\circ} \mathrm{N}$. East of $36^{\circ} \mathrm{W}$ it sometimes turns to the East-Northeast but in most cases it turns to the South-Southwest forming an elongated region of high pressure ridge at the Eastern flank of the NAC. The existence of this high pressure region (ridge) was earlier reported by Krauss et al. (1987).

Two Eastward flows, namely the Central and Southern branches of the NAC, were recorded over the current meter section at $36^{\circ} \mathrm{W}$ between $51^{\circ} \mathrm{N}$ and $52^{\circ} \mathrm{N}$ and near $48^{\circ} \mathrm{N}$. Three return flows were observed also between the Eastward flows and near the Northern and Southern boundaries of the section. This stream structure did not change much from day to day in June, 1990. As a rule, the zonal flows propagated in the water column between $100 \mathrm{~m}$ and $3500 \mathrm{~m}$. The highest velocities were observed in the upper layers. They decreased at 1000 and $2000 \mathrm{~m}$ and slightly increased again in some places near the bottom. The meridional flows presented a large-scale divergence over the section along $36^{\circ} \mathrm{W}$ with the Northward streams North of $49^{\circ} \mathrm{N}$ and Southward streams South of this latitude. There was also a tendency to the formation of a two-layer structure of the meridional streams with the flows near the bottom in the opposite direction to the flows in the remaining part of the water column.

A seamount ( $2600 \mathrm{~m}$ ) was found by the R/V "Akademik Kurchatov" near $49^{\circ} \mathrm{N}$, $36^{\circ} \mathrm{W}$ where only a small bottom elevation up to about $4000 \mathrm{~m}$ is shown on the published bottom charts. Apparently due to the Eastern-Southeast orientation of the elevation and because the height of the elevation was significantly shallower than $4000 \mathrm{~m}$, it can strongly influence the ocean circulation in this region.

The Central Branch of the NAC provides the largest Eastward transport throughout the section along $36^{\circ} \mathrm{W}$. The average value is $62.4 \mathrm{~Sv}$ with variations within 25.3127.4 Sv. These values are comparable with the transport of the same branch in the Northwest Corner estimated by Lazier (1994), who found it equal to $50 \pm 23 \mathrm{~Sv}$.

The mean transport of the Southern Branch of the NAC is smaller and accounts for 48.7 Sv. Approximately the same average value of transport (46.5 Sv) is comprised by the Central and Southern return flows together (supposedly by the Northern and Southern recirculations of the Southern Branch of the NAC). It does not leave much room for the formation of the Eastward flow out from the Southern Branch of the NAC to the East of $36^{\circ} \mathrm{W}$.

The total mean Eastward transport across the section at $36^{\circ} \mathrm{W}\left(53-47^{\circ} \mathrm{N}\right)$ amounts for $111 \mathrm{~Sv}$ and after subtraction of the return flows the transport is equal to $60.9 \mathrm{~Sv}$. It should be noted that according to Byshev et al. (1993) in May-June, 1990 the North Atlantic Current was characterized by the anomalously high intensity. Thus, our estimates of the NAC transport in this period may exceed the typical value.

We are much obliged to two anonymous reviewers for their very helpful comments. This research was funded by state assignment of IO RAS, theme № 0149-2019-0002. 


\section{References}

Arhan M. The North Atlantic Current and Subarctic Intermediate Water. J. Mar. Res., 1990, Vol. 48, No. 1, pp. 109-144.

Arhan M., Colin de Verdier A., and Mercier H. Direct Observation of the Mean Circulation at $48^{\circ}$ $\mathrm{N}$ in the Atlantic ocean. J. Phys. Oceanogr, 1989, Vol. 19, No. 2, pp. 161-181.

Baranov E. Struktura i dinamika vod sistemy Gol'fstrima. (Water Structure and Dynamics of the Gulf Stream System). Moscow: Hydrometeoizdat, 1988, 252 p. [In Russian].

Baranov E.I. and Gincul V.G. Dynamics of Water of the Newfoundland Energy-Active Zone. Soviet Meteorology and Hydrology, New York: Allerton Press Inc., 1984, No. 12, pp. 64-68.

Baryshevskaya G.I. Current of the Gulf Stream System and Atlantic Temperature Regime. Moscow: Hydrometeoizdat, 1990, 139 p. [In Russian].

Baryshevskaya G.I. Variability of Discharge in the Central North Atlantic Current. Soviet Meteorology and Hydrology, New York: Allerton Press Inc., 1985, No. 2, pp. 51-61.

Bubnov V.A. The North Atlantic Current by the Atlantex-90 Experimental Data. Oceanology, English Edition, 1994, Vol. 34, No. 6, pp. 733-737.

Byshev V.I. Properties of an Intra-Thermocline Lens on a Subpolar Front in the North Atlantic. Oceanology, English Eddition, 1992, Vol. 32, No. 6, pp. 701-706.

Byshev V.I., Koprova L.I., Navrotskaya S.E., Pozdnyakova T.G., and Romanov Ya.A. The Abnormal Condition of Newfoundland Energy-Active Zone in 1990. Doklady Akademii Nauk, Geophys., 1993, Vol. 331, No. 6, pp. 735-793, [In Russian].

Byshev V.I., Koprova L.I., and Romanov Yu.A. Formation of Sea Surface Temperature Anomalies in the Newfoundland Energy Active Zone in May-June 1990. Russian Meteorology and Hydrology, 1996, No. 7, pp. 78-88, [In Russian].

Chuan Shi and Shenn-Yu Chao. Eastward Jets over Diverging Isobath with Applications to the Gulf Stream past the Grand Banks. J. Geophys. Res., 1994, Vol. 99(C11), pp. 22689-22706.

Clarke R.A., Hill H., Reneger R.F., and Warren B.A. Current System South and East of the Grand Banks of Newfoundland. J. Phys. Oceanogr., 1980, Vol. 10(1), pp. 25-65.

Dietrich G., Kalle K., Krauss W., and Siedler G. General Oceanography. New York: John Wiley, $1975,626 \mathrm{p}$.

Fahrbarch E. and Warge G. Observations of the Persistent Pattern in the Temperature Field Related to the North Atlantic Current. Dtsch. Hydrogr. Z., 1987, Vol. 40(4), pp. 141-155.

Gana S. and Provost C. Circulation and Fluxes of the Central North Atlantic in 1983/1984 Estimated by Inverse Analysis of TOPOGULF Hydrographic Data. J. Mar. Syst., 1993, No. 4, pp. 67-92.

Gladyshev S.V., Gladyshev V.S., Sokov A.V., Gulev S.K., Pautova L.A., Demidov A.B. Average annual structure and transport of waters Eastward of Greenland by the system of western boundary currents. Doklady Earth Sciences. 2017. T. 473. № 1. C. 313-317.

Gulev S.K., Ivanov Yu.A., Kolinko A.V., Lappo S.S., and Morozov E.G. The "Atlantex-90" Experiment. Soviet Meteorology and Hydrology, by Allerton Press. Inc., New York, 1992, No. 5, pp. 37-45.

Hardtke P.G. and Meincke J. Kinematical Interpretation of Infrared Surface Pattern in the North Atlantic. Oceanol. Acta., 1984, Vol. 7(3), pp. 373-378.

Heywood K.J., McDonagh E.L., and White M.A. Eddy Kinetic Energy of the North Atlantic Subpolar Gyre from Satellite Altimetry. J. Geophys. Res., 1994, Vol. 99(Cl 1), pp. 22525-22539. 
Ivanov Yu.A. et al.

International Geological-Geophysical Atlas of the Atlantic Ocean. Ed. by Udinsev G.B., Moscow: IOC of UNESCO, 1989-1990.

Ivanov Yu.A. and Morozov E.G. Water Transport in the Gulf Stream Delta. Doklady Akademii Nauk USSR, 1991, Vol. 319(2), pp. 487-490, [in Russian].

Koprova L.I. and Romanov Yu.A. The Horizontal Structure of Thermal Fronts of the North Atlantic Surface Drift. Russian Meteorology and Hydrology, New York: Allerton Press. Inc., 1993, No. 4, pp. 61-69.

Krauss W. The North Atlantic Current. J. Geoph. Res., 1986, Vol. 91(C4), pp. 5061-5074.

Krauss W., Fahrbach E., Aitsam A., Elken J., and Koske P. The North Atlantic Current and its Associated Eddy Field SouthEast of Flemish Cap. Deep-Sea Res., 1987, Vol. 34(7), pp. 1163-1183.

Krauss W., Kase R.N., and Hinrichsen H.H. The Branching of the Gulf Stream SouthEast of the Grand Banks. J. Geophys. Res., 1990, Vol. 95(C8), pp. 13089-13103.

Lasier J.R.N. Observations in the Northwest Corner of the North Atlantic Current. J. Phys. Oceanogr., 1994, Vol. 24(7), pp. 1449-1463.

Leach H. The Analysis of Currents Measured from a Moving Ship in the North Atlantic Polar Front. Deep-Sea Res., 1986, Vol. 33(8), pp. 1069-1081.

Leach H. Interannual Variability in the Upper Ocean in the North Atlantic, Summer 1983 and 1986. Deep-Sea Res., Part A., 1990, Vol. 37(7), pp. 1169-1176.

Mann C.R. The Termination of the Gulf Stream and the Beginning of the North Atlantic Current. Deep-Sea Res., 1967, Vol. 14(3), pp. 337-358.

Mann C.R. A Review of Branching of the Gulf Stream System. Proceedings of the Royal Society of Edinburgh: Set. B. Biol. Sci., 1972, Vol. 72, pp. 341-349.

McCartney M.S. and Talley L.D. The Subpolar Mode Water of the North Atlantic Ocean. J. Phys. Oceanogr., 1982, Vol. 12(12), pp. 1169-1188.

Romanov Yu.A., Pozdnyakova T.G., and Filippov I.A. The Facsimile Charts of the SST in the North Atlantic. Russian Meteorology and Hydrology, New York: Allerton Press. Inc., 1991, No. 12, pp. 92-95.

Stommel H., Niiler P., and Anati D. Dynamic Topography and Recirculation of the North Atlantic. J. Mar. Res., 1978, Vol. 36(3), pp. 449-468.

Sy A. Investigation of Large Scale Circulation Patterns in the Central North Atlantic: The North Atlantic Current, the Azores Current, and the Mediterranean Water Plume in the Area of the Mid-Atlantic Ridge. Deep-Sea Res., Part A, 1988, Vol. 35(3), pp. 383-413.

Sy A., Schauer U., and Meincke J. The North Atlantic Current and its Associated Hydrographic Structure above and Eastward of the Mid-Atlantic Ridge. Deep-Sea Res., Part A, 1992, Vol. 39, pp. 825-853.

Warren B. Divergence of Isobaths as a Cause of Current Branching. Deep-Sea Res., Suppl. to 16, 1969, pp. 339-355.

Worthington L.V. On the North Atlantic Circulation. Oceanographic Studies, 1976, Vol. 6, pp. 1-110. 


\title{
О СТРУКТУРЕ СЕВЕРНО - АТЛАНТИЧЕСКОГО ТЕЧЕНИЯ В МАЕ-ИЮНЕ 1990 г.
}

\author{
Иванов Ю.А., Бышев В.И., Романов Ю.А., Сидорова А.Н. \\ Институт океанологии им. П.П. Ширшова РАН, 117997, Москва, \\ Нахимовский проспект, д.36, e-mail: byshev.v@mail.ru \\ Статья поступила в редакцию 15.01.2019, одобрена к печати 30.05.2019
}

В рамках отечественного проекта «Разрезы», включенного в международную программу WOCE, в 1990 г. были выполнены комплексные гидрофизические исследования Ньюфаундлендской энергоактивной зоны, в которых приняли участие научно исследовательские суда (НИС) Института океанологии им. П.П. Ширшова «Витязь» (19-й рейс), «Профессор Штокман» (26-й рейс) и «Академик Курчатов» (50-й рейс) и 4 судна других ведомств. Научное руководство общей программой работ экспедиции, получившей название «Атлантэкс-90», осуществлял профессор Ю.А. Иванов. В качестве основной задачи программа предусматривала исследование пространственновременной короткопериодной изменчивости динамики вод крупномасштабной системы Гольфстрим-Северо-Атлантическое течение. С этой целью в мае-июне 1990 г. НИС «Академик Курчатов» выполнил несколько разрезов, пересекающих главные гидрологические фронты Ньюфаундлендской энергоактивной зоны (45-53².ш., 36-45⒊д.). Наблюдения велись с помощью кабельных зондов с датчиками температуры, электропроводности и давления (СТД) и обрывных зондирующих устройств (теряемый батитермограф-ТБТ). Вся эта аппаратура в виде малых серий была изготовлена и прошла метрологическую аттестацию в ОКБ Океанологической техники ИОАН СССР. Вдоль всего маршрута НИС проводились наблюдения температуры поверхности океана (ТПО). На разрезе от $47^{\circ}$ до $53^{\circ}$ с.ш. вдоль меридиана $36^{\circ}$ 3.д. в продолжение около одного месяца велись измерения скорости течений на 14 заякоренных буйковых станциях с помощью приборов марки ПОТОК производства ОКБ ОТ ИОАН, установленных на горизонтах 100, 200, 1000, 2000, 3500 м. В дополнение к данным собственных измерений в течение всего периода наблюдений по радиоканалу связи принимались факсимильные карты ТПО из ближайших гидрометеорологических обсерваторий.

Анализ полученных данных показал, что за период наблюдений Северо- Атлантическое течение (САТ) разделялось на две ветви (Центральную и Южную) примерно в окрестности 47,5-48 с.ш., где изобата 4500 м поворачивала на восток под прямым углом к изобате 4000 м. После точки бифуркации Центральная ветвь вначале сохраняла северное направление, затем поворачивала на северо-запад вдоль изобаты 4000 м, и далее, разворачиваясь на восток, пересекала меридиан $36^{\circ} 3$.д. между $51^{\circ}$ и $52^{\circ}$ с.ш. Перед этим, временами Центральная ветвь приближалась к меридиану $36^{\circ} 3 . д$. около $50^{\circ}$ с.ш., затем отклонялась на север, северо-запад и, наконец, поворачивала на северо-восток около $51,5^{\circ}$ с.ш. Южная ветвь САТ после раздвоения потока следовала приблизительно изобате 4500 м и пересекала меридиан $36^{\circ}$ з.д. около $48^{\circ}$ с.ш. К востоку от $36^{\circ}$ 3.д. она временами могла иметь восточное, северо-восточное направление, но обычно разворачивалась на юг, юго-запад, формируя высокий гребень динамической высоты поверхности океана на восточном фланге САТ. Три возвратных потока наблюдались на разрезе по $36^{\circ}$ 3.д. Один из потоков отмечен между Центральной и Южной ветвями САТ, а два других были зарегистрированы на северном и южном краях разреза. Такая структура поля скорости фактически сохранялась неизменной в течение июня 1990 г. Основные зональные потоки наблюдались практически во всей водной толще в слое от 100 м до 3500 м. Самые высокие скорости были характерны для верхней части этого слоя. На глубинах 1000-2000 м скорости заметно ослабевали, вновь несколько возрастая в отдельных местах у дна. Распределение меридиональной компоненты скорости течения по данным измерений на буях позволило обнаружить 
Ivanov Yu.A. et al.

наличие крупномасштабной дивергенции, располагавшейся вдоль разреза по $36^{\circ}$ з.д. К северу и к югу от широты около $49^{\circ}$ направления меридиональных компонент скорости течений оказались противоположными, что характерно для расходящихся потоков, формирующих дивергенцию в поле скорости течений. При анализе материалов наблюдений было обращено внимание на то, что важную роль в формировании структуры циркуляции океана в районе исследований могла играть подводная гора ( 2600 м), зарегистрированная эхолотами НИС «Академик Курчатов» вблизи $49^{\circ}$ с.ш., $36^{\circ}$ з.д. Результаты измерений и расчетов показали, что средний за весь период наблюдений перенос Центральной ветви САТ через 36³.д. составлял 62,4 Св. Эта величина сопоставима с переносом САТ, оцененным четырьмя годами позже Лазиером (1994) 50 23 Св. примерно для того же района, где проводились наши работы в 1990 г. Приблизительно такой же средний перенос (46,5 Св.) осуществлялся двумя возвратными потоками (предположительно Северной и Южной рециркуляциями Южной ветви САТ). В целом средний перенос вод в восточном направлении через разрез по $36^{\circ}$ 3.д. достигал 111 Св., а после вычитания обратных потоков составил 60,9 Св.

Ключевые слова: Северо-Атлантическое течение, Азорское течение, СрединноАтлантический хребет, Лабрадорское течение, Гольфстрим, программа WOCE, межведомственная программа «РАЗРЕЗЫ», 50-й рейс НИС «Академик Курчатов»

\section{Литература}

Баранов Е.И. Структура и динамика вод системы Гольфстрима. М.: Гидрометеоиздат, 1988. $252 \mathrm{c}$.

Баранов Е.И., Гинкул В.Г. Динамика вод Ньюфаундлендской энергоактивной зоны // Метеорология и гидрология. 1984. № 12. С. 78-84.

Барышевская Г.И. Течения системы Гольфстрима и температурный режим Северной Атлантики. М.: Гидрометеоиздат, 1990. $139 \mathrm{c.}$

Барышевская Г.И. Изменчивость расхода в центральной части Северо-Атлантического течения // Метеорология и гидрология. 1985. № 2. С. 77-87.

Бубнов В.А. Северо-Атлантическое течение по данным эксперимента "Атлантекс-90" // Океанология. 1994. Т. 34. № 6. С. 805-809.

Бышев В.И. О некоторых особенностях внутритермоклинной линзы на субполярном фронте в Северной Атлантике // Океанология. 1992. Т. 32. С. 1012-1018.

Бышев В.И., Копрова Л.И., Навроикая С.Е., Позднякова Т.Г., Романов Ю.А. Аномальное состояние Ньюфаундлендской энергоактивной зоны в 1990 г. // ДАН. 1993. Т. 331. № 6. С. 735-738.

Бышев В.И., Копрова Л.И., Романов Ю.А. О формировании аномалий температуры поверхности океана в районе Ньюфаундлендской энергоактивной зоны в мае-июне 1990 г. // Метеорология и гидрология. 1996. № 7. С. 78-88.

Гладышев В.С., Соков А.В., Гулев С.К., Паутова Л.А., Демидов А.Б. Среднемноголетняя структура и перенос вод системой западных пограничных течений восточнее Гренландии // ДАН. 2017. Т. 473. № 1. С. 93-97.

Гулёв С.К., Иванов Ю.А., Колинко А.В., Лаппо С.С., Морозов Е.Г. Эксперимент “Атлантекс-90" // Метеорология и гидрология. 1992. № 5. С. 51-61.

Иванов Ю.А., Морозов Е.Г. Перенос вод в дельте Гольфстрима // ДАН. 1991. Т. 319. № 2. C. $487-490$.

Копрова Л.И., Романов Ю.А. О горизонтальной структуре термических фронтов СевероАтлантического течения на поверхности океана // Метеорология и гидрология. 1993. № 4. С. $76-84$.

Международный геолого-геофизический атлас Атлантического океана. (под ред. Г.Б. Удинцева). М.: 1989-1990 гг. 158 с. 
Романов Ю.А., Позднякова Т.Г., Филиппов И.А. О факсимильных картах ТПО Северной Атлантики // Метеорология и гидрология. 1991. № 12. С. 92-95.

Arhan M. The North Atlantic Current and Subarctic Intermediate Water // J. Mar. Res. 1990. Vol. 48. No. 1. P. 109-144.

Arhan M., Colin de Verdier A., Mercier H. Direct Observation of the Mean Circulation at $48^{\circ} \mathrm{N}$ in the Atlantic Ocean // J. Phys. Oceanogr. 1989. Vol. 19. No. 2. P. 161-181.

Chuan Shi, Shenn-Yu Chao. Eastward Jets over Diverging Isobath with Applications to the Gulf Stream past the Grand Banks // J. Geophys. Res. 1994. Vol. 99(C11). P. 22689-22706.

Clarke R.A., Hill H., Reneger R.F., Warren B.A. Current System South and East of the Grand Banks of Newfoundland // J. Phys. Oceanogr. 1980. Vol. 10(1). P. 25-65.

Dietrich G., Kalle K., Krauss W., Sidler G. General Oceanography. New York: John Wiley, 1975. $626 \mathrm{p}$.

Fahrbarch E., Warge G. Observations of the Persistent Pattern in the Temperature Field Related to the North Atlantic Current // Dtsch. Hydrogr. Z. 1987. Vol. 40(4). P. 141-155.

Gana S., Provost C. Circulation and Fluxes of the Central North Atlantic in 1983/1984 Estimated by Inverse Analysis of TOPOGULF Hydrographic Data // J. Mar. Syst. 1993. No. 4. P. 67-92.

Hardtke P.G., Meincke J. Kinematical Interpretation of Infrared Surface Pattern in the North Atlantic // Oceanol. Acta. 1984. Vol. 7(3). P. 373-378.

Heywood K.J., McDonagh E.L., White M.A. Eddy Kinetic Energy of the North Atlantic Subpolar Gyre from Satellite Altimetry // J. Geophys. Res. 1994. Vol. 99(Cl 1). P. 22525-22539.

Krauss W. The North Atlantic Current// J. Geoph. Res. 1986. Vol. 91(C4). P. 5061-5074.

Krauss W., Fahrbach E., Aitsam A., Elken J., Koske P. The North Atlantic Current and its Associated Eddy Field SouthEast of Flemish Cap // Deep-Sea Res. 1987. Vol. 34(7). P. 1163-1183.

Krauss W., Kase R.N., Hinrichsen H.H. The Branching of the Gulf Stream SouthEast of the Grand Banks // J. Geophys. Res. 1990. Vol. 95(C8). P. 13089-13103.

Lasier J.R.N. Observations in the Northwest Corner of the North Atlantic Current // J. Phys. Oceanogr. 1994. Vol. 24(7). P. 1449-1463.

Leach H. Interannual Variability in the Upper Ocean in the North Atlantic, Summer 1983 and 1986 // Deep-Sea Res. Part A. 1990. Vol. 37(7). P. 1169-1176.

Leach $H$. The Analysis of Currents Measurements from a Moving Ship in the North Atlantic Polar Front // Deep-Sea Res. 1986. Vol. 33(8). P. 1069-1081.

Mann C.R. A Review of Branching of the Gulf Stream System // Proceedings of the Royal Society of Edinburgh: Set. B. Biol. Sci. 1972. Vol. 72. P. 341-349.

Mann C.R. The Termination of the Gulf Stream and the Beginning of the North Atlantic Current // Deep-Sea Res. 1967. Vol. 14(3) P. 337-358.

McCartney M.S., Talley L.D. The Subpolar Mode Water of the North Atlantic Ocean // J. Phys. Oceanogr. 1982. Vol. 12(12). P. 1169-1188.

Stommel H., Niiler P., Anati D. Dynamic Topography and Recirculation of the North Atlantic // J. Mar. Res., 1978, Vol. 36(3), pp. 449-468.

Sy A. Investigation of Large Scale Circulation Patterns in the Central North Atlantic: The North Atlantic Current, the Azores Current, and the Mediterranean Water Plume in the Area of the Mid-Atlantic Ridge // Deep-Sea Res. Part A. 1988. Vol. 35(3). P. 383-413.

Sy A., SchauerU., Meincke J. The North Atlantic Current and its Associated Hydrographic Structure above and Eastward of the Mid-Atlantic Ridge // Deep-Sea Res. Part A. 1992. Vol. 39. P. 825-853.

Warren B. Divergence of Isobath as a Cause of Current Branching // Deep-Sea Res. Suppl. to 16. 1969. P. 339-355.

Worthington L.V. On the North Atlantic Circulation // Oceanographic Studies. 1976. Vol. 6. P. $1-110$. 